\title{
Beneath Still Waters - Multistage Aquatic Exploitation of Euryale ferox (Salisb.) during the Acheulian
}

\author{
Naama Goren-Inbar ${ }^{1}$, Yoel Melamed ${ }^{2}$, Irit Zohar ${ }^{3}$, Kumar \\ Akhilesh $^{4}$ and Shanti Pappu ${ }^{4,5}$
}

Cite this as: Goren-Inbar, N., Melamed, Y., Zohar, I., Akhilesh, K. and Pappu, S. (2014). Beneath Still Waters - Multistage Aquatic Exploitation of Euryale ferox (Salisb.) during the Acheulian. 'Human Exploitation of Aquatic Landscapes' special issue (ed. Ricardo Fernandes and John Meadows), Internet Archaeology. doi:10.11141/ia.37.1

1. Institute of Archaeology, The Hebrew University of Jerusalem, Mt Scopus, Jerusalem 91905, Israel. Email: goren@cc.huji.ac.il

2. The Mina and Everard Goodman Faculty of Life Sciences, Bar-Ilan University, Ramat-Gan 5290000, Israel.

3. National Natural History Collections, Berman Building, Edmond J. Safra Campus, The Hebrew University of Jerusalem, Givat Ram, Jerusalem 91904, Israel.

4. Sharma Centre for Heritage Education, 28, I Main Road, C.I.T. Colony, Mylapore, Chennai 600004, Tamil Nadu, India. Email:akhilarchaeo@gmail.com / sharmaheritage@gmail.com

5. Department of Archaeology, Deccan College Postgraduate and Research Centre, Pune 411006, India

Keywords: Acheulian; Gesher Benot Ya'aqov; India; Aquatic exploitation; E. ferox

This issue has been funded by the Graduate School "Human Development in Landscapes", University of Kiel with additional funding from the Institute for Ecosystem Research, University of Kiel and theCentre for Baltic and Scandinavian Archaeology, Schloss Gottorf.

(C) Author(s). Except where otherwise noted, content from this work may be used under the terms of the Creative Commons Attribution 3.0 Unported licence, which permits unrestricted use, 
distribution, and reproduction in any medium, provided that attribution to the author(s), the title of the work, the Internet Archaeology journal and the relevant URL/DOI is given.

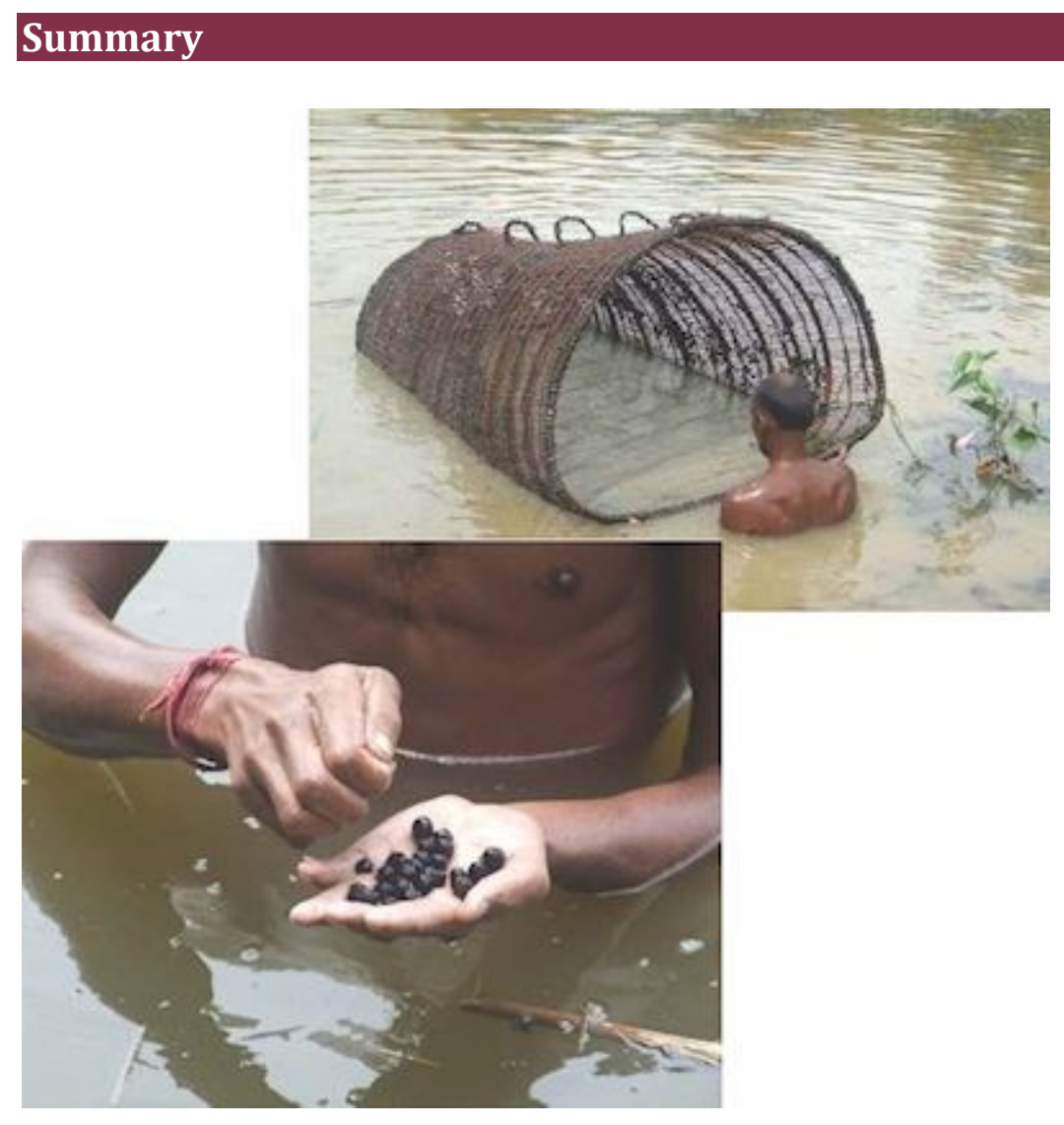

Remains of the highly nutritious aquatic plant Fox nut - Euryale ferox Salisb. (Nymphaeaceae) - were found at the Acheulian site of Gesher Benot Ya'aqov, Israel. Here, we present new evidence for complex cognitive strategies of hominins as seen in their exploitation of $E$. ferox nuts. We draw on excavated data and on parallels observed in traditional collecting and processing practices from Bihar, India. We suggest that during the early Middle Pleistocene, hominins implemented multistage procedures comprising underwater gathering and subsequent processing (drying, roasting and popping) of $E$. ferox nuts. Hierarchical processing strategies are observed in the Acheulian lithic reduction sequences and butchering of game at this and other sites, but are poorly understood as regards the exploitation of aquatic plant resources. We highlight the ability of Acheulian hominins to resolve issues related to underwater gathering of $E$. ferox nuts during the plant's life cycle and to adopt strategies to enhance their nutritive value. 


\section{List of Figures}

Figure 1: Fox nut (E. ferox) from Gesher Benot Ya'aqov Layer II-6 Level 1, complete seed with its characteristic germination aperture and attachment scar (hilum). (Image credit: authors)

Figure 2: Map showing: (A) General view of the location of the regions studied in Israel and India; (B) Location of the Acheulian site of Gesher Benot Ya'aqov,

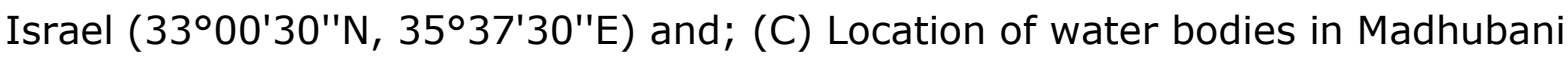
District, Bihar, India where traditional methods of gathering and processing $E$. ferox are practiced. The water bodies studied are located within a radius of

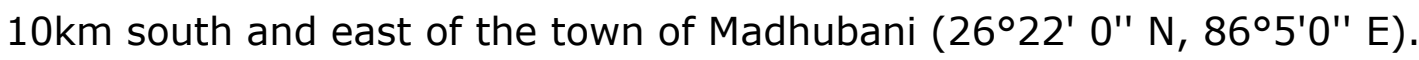
(Image credit: authors)

Figure 3: E. ferox seed remains from GBY: (A) Fox nut (E. ferox, GBY Layer II-6 Level 1 ), seed coat fragments easily identified by their characteristic attachment scar (hilum) close to the germination aperture (appears in the right fragment) (SEM); (B) Fox nut (E. ferox, GBY Layer II-6 Level 1), seed coat fragments, eight showing the convex outer side and three the concave inner side; (C) Fox nut (E. ferox, GBY Layer III-7), complete and compressed seeds. (Image credit: authors)

Figure 4: Flow charts highlighting the main events in the gathering and processing of $E$. ferox (locally called Makhana) based on our ethnographic observations in Madhubani District, Bihar and summarised from published literature (Jha et al. 1991; 2003; Mishra et al. 2003; Mandal et al. 2010). (Image credit: authors)

Figure 5: Procedures involved in the collection of E. ferox nuts, Madhubani District, Bihar, India; (A) General view of men of the fishing community involved in the gathering of $E$. ferox (Makhana) nuts; note one type of collecting basket in the background; (B) Close-up of E. ferox, showing the flower and characteristic leaves; (C) View of a diver manipulating a bamboo pole that aids in demarcating areas selected for underwater gathering of $E$. ferox nuts; (D) Diver surfacing after gathering $E$. ferox nuts using a special type of basket (Gaanja), with an aluminum pot also used for collection; (E) Adolescent boy collecting stray nuts that rise to the water surface from the pond bed during collection; $(F)$ Divers 
(underwater) manipulating a large basket (Auka) in which nuts are collected. Note the two hands at the edge of the basket. (Image credit: authors)

Figure 6: Procedures involved in the collection of E. ferox nuts, Madhubani District, Bihar, India: (A) Diver with the basket that is rotated within water to cleanse the nuts; (B) Divers bring the basket to the shore to complete the process of cleansing the nuts; (C) Close-up of the collected nuts; (D) View of the E. ferox nuts with associated molluscs; (E) Trampling helps remove the pulp; F) A mound of nuts piled up near the water body ready for transport to the village. (Image credit: authors)

Figure 7: Procedures involved in processing of $E$. ferox nuts, Madhubani District, Bihar, India: (A) E. feroxnuts are spread out to dry in the sun in the village; (B) The nuts are sorted into differing size ranges using sieves of different dimensions; (C) The nuts are roasted and stirred using bamboo sticks; (D) Popping of the $E$. ferox nuts immediately after roasting; note the wooden anvil and hammer; (E) View of the popped E. ferox nuts ready to be eaten. (Image credit: authors)

Figure 8: Hammer and anvil used for popping the dried and roasted E. ferox nuts in traditional practices in Madhubani District, Bihar, India: (A) General view of a wooden hammer (Thaapi) (photograph: Gabi Laron); (B) A wooden anvil (Aphara); (C) Measurements of a typical hammer; (D) Close-up of an anvil used for popping $E$. ferox nuts. (Image credit: authors)

Figure 9: Debris of E. ferox nuts after popping: (A) A handful of nuts (eight in number) generally popped together ( $\mathrm{N}=50$ fragments varying from $1 \mathrm{~mm}$ to $1 \mathrm{~cm}$, the rest being $<1 \mathrm{~mm}$ ). At the top right of the image, note a complete roasted nut of the same size group (diameter $=11.49 \mathrm{~mm}$ ) as well as the final poppedMakhana; (B) Close-up of nut fragments showing inner concave side; (C) One roasted Makhana nut ( $\mathrm{N}=5$ fragments) after popping. (Image credit: authors)

Figure 10: Anvils at the site of Gesher Benot Ya'aqov: A) Pitted anvils; B) Thin anvil. (Image credit: authors) 


\section{List of Tables}

Table 1: Nuts and shell fragments of E. ferox and T. natans at GBY (updated from previous work). Apart from layers/levels noted below, pitted stones (without botanical remains) were also found in Layer $\mathrm{V}-4$ : $\mathrm{N}=1$; Layer $\mathrm{V}-5$ : $\mathrm{N}=4$; Jordan Bank (Layers V-5 and V- 6 excavated together under water): $\mathrm{N}=7+2$ anvils; Layer II-6 Level 4b: $\mathrm{N}=26+2$ anvils.

Table 2: Common aquatic taxa from the Upper Jordan Valley (Lake Hula) (Danin 2004), the Acheulian site of GBY and Bihar (India) (Melamed 2003; Melamed et al. 2011). Data on fish from Goren and Ortal 1999; Zohar and Biton 2011; Montana et al. 2011. In Bihar, 35 species have a high commercial value, among which Cyprinidae and Clariidae predominate, as well as Balitoridae. The richness of native fish species here is very high ( $>260$ species), thus differing from that of Lake Hula, similarities being at the family level (Cyprinidae predominate in both Bihar and GBY).

Table 3: Edible species reported from GBY, including details of parts that can be consumed. 


\section{Introduction}

Studies of the evolution of hominin cognitive abilities and the origins of intelligence and language focus primarily on stone tool manufacture and on the exploitation of medium-sized to large terrestrial mammals. Here, we examine additional aspects of these cognitive abilities as reflected in a little-known example of skilled behaviour patterns: the exploitation of aquatic flora and fauna in the wetland habitats of paleo-Lake Hula. Although wetlands play an important role in supplementing human diet and enhancing its nutritional balance (Joordens et al. 2009; Wrangham et al. 2009; Cunnane and Steward 2010), few studies have explored the nutritional and/or medicinal properties of wetlands plants in the archaeological context (Stewart 1994; 2010; Colonese et al. 2011; Cortés-Sánchez et al. 2011; Hardy and Moncel 2011; Verhaegen and Munro 2011).

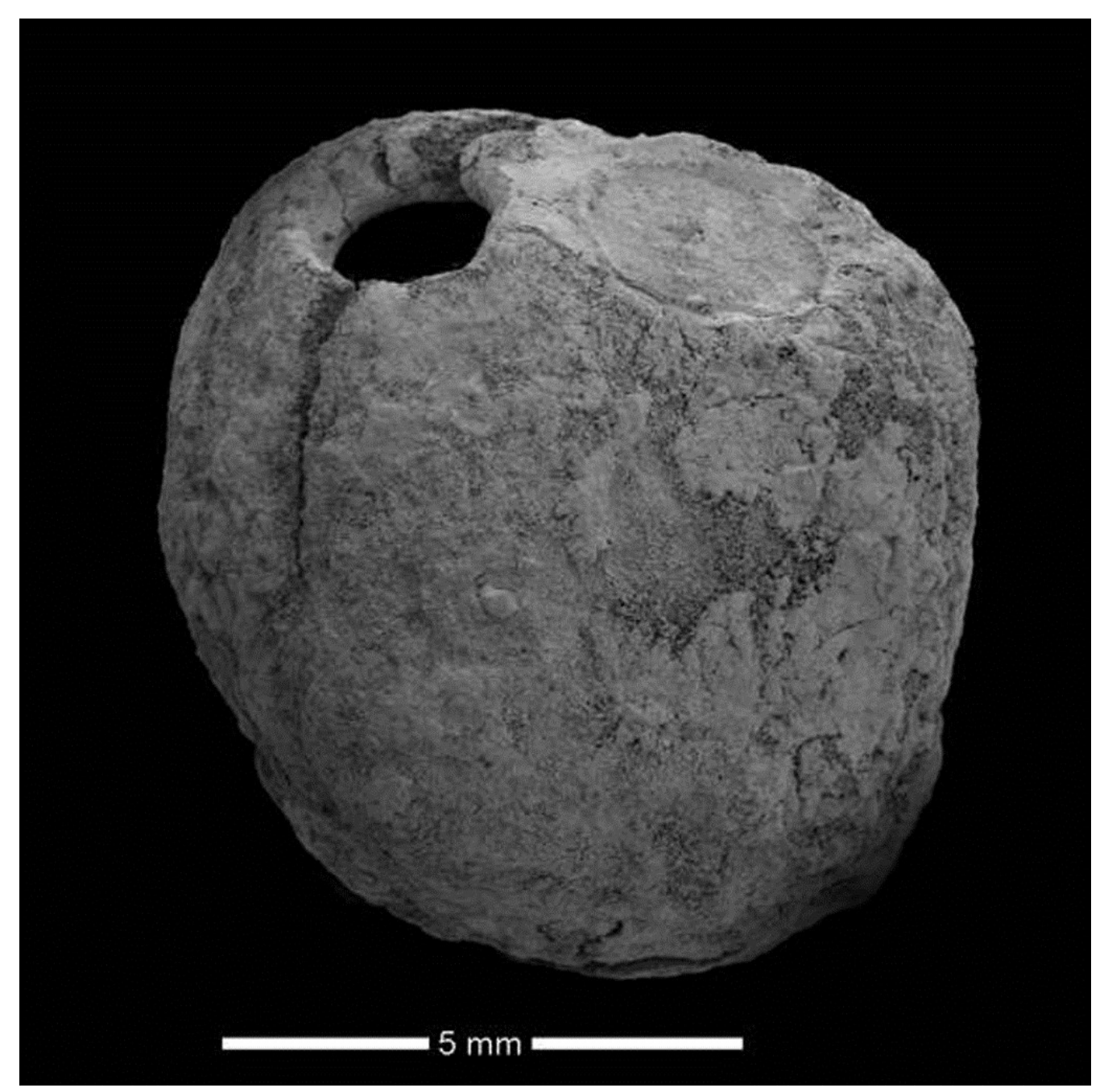

Figure 1: Fox nut (E. ferox) from Gesher Benot Ya'aqov Layer II-6 Level 1, complete seed with its characteristic germination aperture and attachment scar (hilum). (Image credit: authors) 
Nuts of the aquatic plant Euryale ferox Salisb. (Nymphaeaceae) (common names: Fox nut, Gorgon nut, Prickly water lily and Makhana in Bihar, India) (Figure 1) were identified in Early to Middle Pleistocene deposits (Marine Isotope Stages 18-20) at the site of Gesher Benot Ya'aqov (GBY), Israel (Goren-Inbar et al. 2000; Feibel 2004; Sharon et al. 2011) (Figure 2). Along with Trapa natans (Water chestnut), they formed part of the botanically rich aquatic habitat of paleo-Lake Hula, comprising over 24 species of water plants (Table 1 ). Both species are currently extinct in the Levant (Melamed 2003; Melamed et al. 2011). E. ferox and T. natans are floating annual aquatic plants that grow in low-energy or still-water bodies generally around $1.5 \mathrm{~m}$ deep, occurring within a wetlands ecosystem that was exploited by the GBY Acheulian hominins (Melamed 2003; Ashkenazi et al. 2005; Ashkenazi et al. 2009; Spiro et al. 2009; Mienis and Ashkenazi 2011; Zohar and Biton 2011). The prickly nature of $E$. ferox renders gathering and processing its nuts far more difficult in comparison with those of $T$. natans, thus providing us with an opportunity to explore the ways in which this species was exploited at GBY.

Here, we present novel evidence for advanced cognitive abilities of Acheulian hominins at GBY as attested by their adoption of complex multistage procedures for collecting and processing $E$. ferox nuts. E. ferox is widely prevalent in tropical and subtropical regions in ecological contexts similar to those of the paleo-Lake Hula environment. In many such places, it is collected and processed using traditional methods by predominantly freshwater fishing communities (Jha et al. 1991; 2003). The range of these strategies, particularly evident in the water bodies of northern Bihar (Madhubani District, India) (Figure 2), is of immense relevance when examining the archaeological context of $E$. ferox nut remains at GBY.

The Acheulian site of GBY, situated within the Benot Ya'akov Formation (Belitzky 2002), is located on the shores of paleo-Lake Hula in the Upper Jordan Valley, Dead Sea Rift (Goren-Inbar et al. 2000). This Early to Middle Pleistocene sedimentary sequence documents an oscillating freshwater lake and represents $\sim 100,000$ years of hominin occupation (Marine Isotope Stages 18-20) beginning earlier than 790,000 years ago (Feibel 2001; 2004). Studies of the 15 excavated archaeological horizons indicate that Acheulian hominins repeatedly occupied lake margins, produced stone tools, systematically butchered and exploited animals, gathered plant food, and controlled fire (Goren-Inbar et al. 1994; 2002a; 2002b; 2004; Rabinovichet al. 2008; Alperson-Afil et al. 2009). 


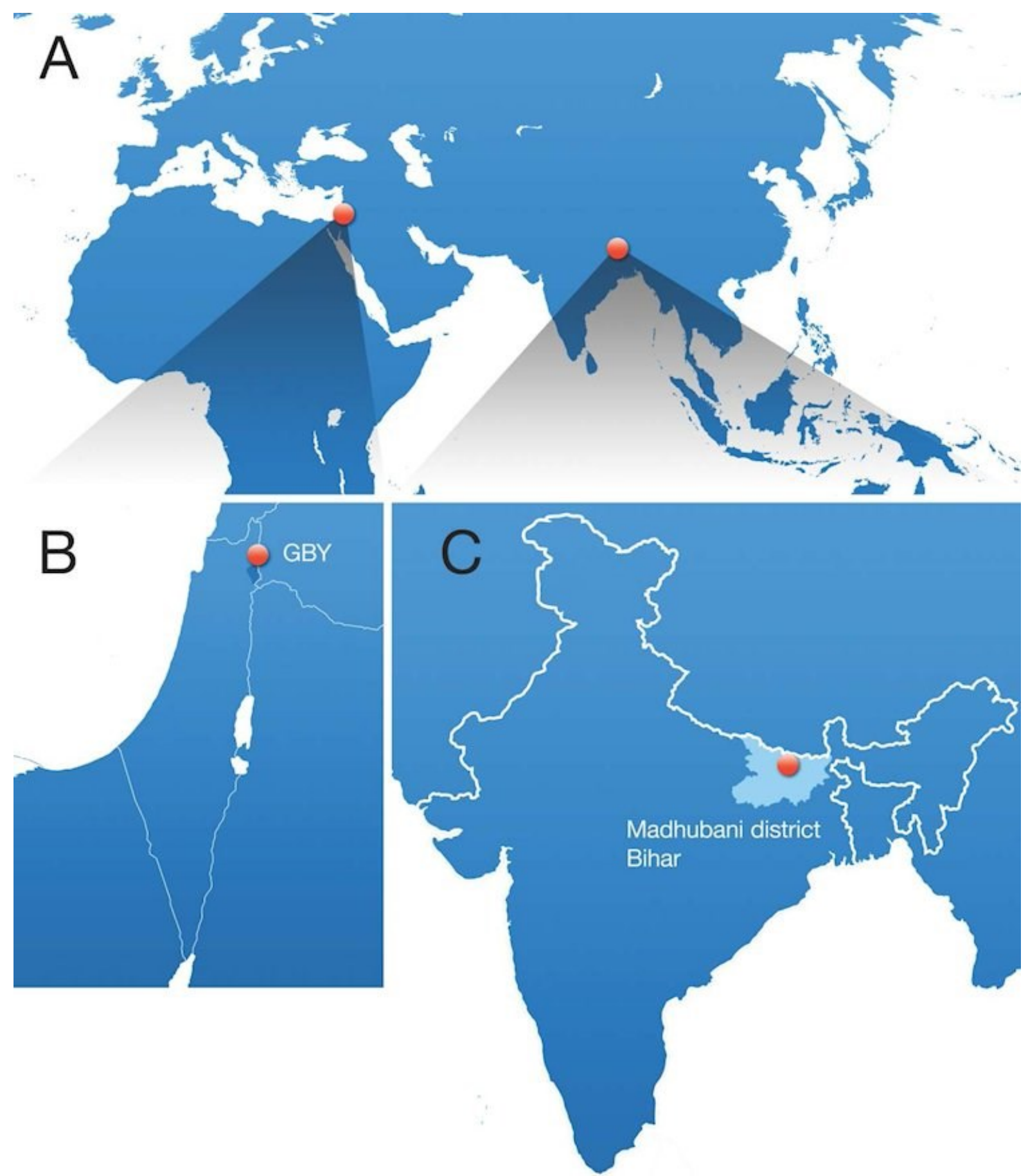

Figure 2: Map showing: (A) General view of the location of the regions studied in Israel and India; (B) Location

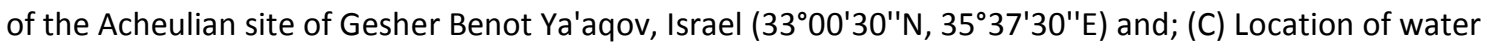
bodies in Madhubani District, Bihar, India where traditional methods of gathering and processing $E$. ferox are practiced. The water bodies studied are located within a radius of $10 \mathrm{~km}$ south and east of the town of Madhubani ( $\left.26^{\circ} 22^{\prime} 0^{\prime \prime} \mathrm{N}, 86^{\circ} 5^{\prime} \mathrm{O}^{\prime \prime} \mathrm{E}\right)$. (Image credit: authors) 


\section{Euryale ferox (Salisb.)}

Remains of Euryale ferox nuts (seeds in botanical terminology) at GBY were identified by their characteristic features such as the prominent longitudinal ridge (raphe), shape and location of the operculum and hilum, as well as the structure of the seed surfaces (Figures 1,3). These characteristics distinguish Euryale feroxfrom related fossil genera such as Palaeoeuryale and Pseudoeuryale (Miki 1960).
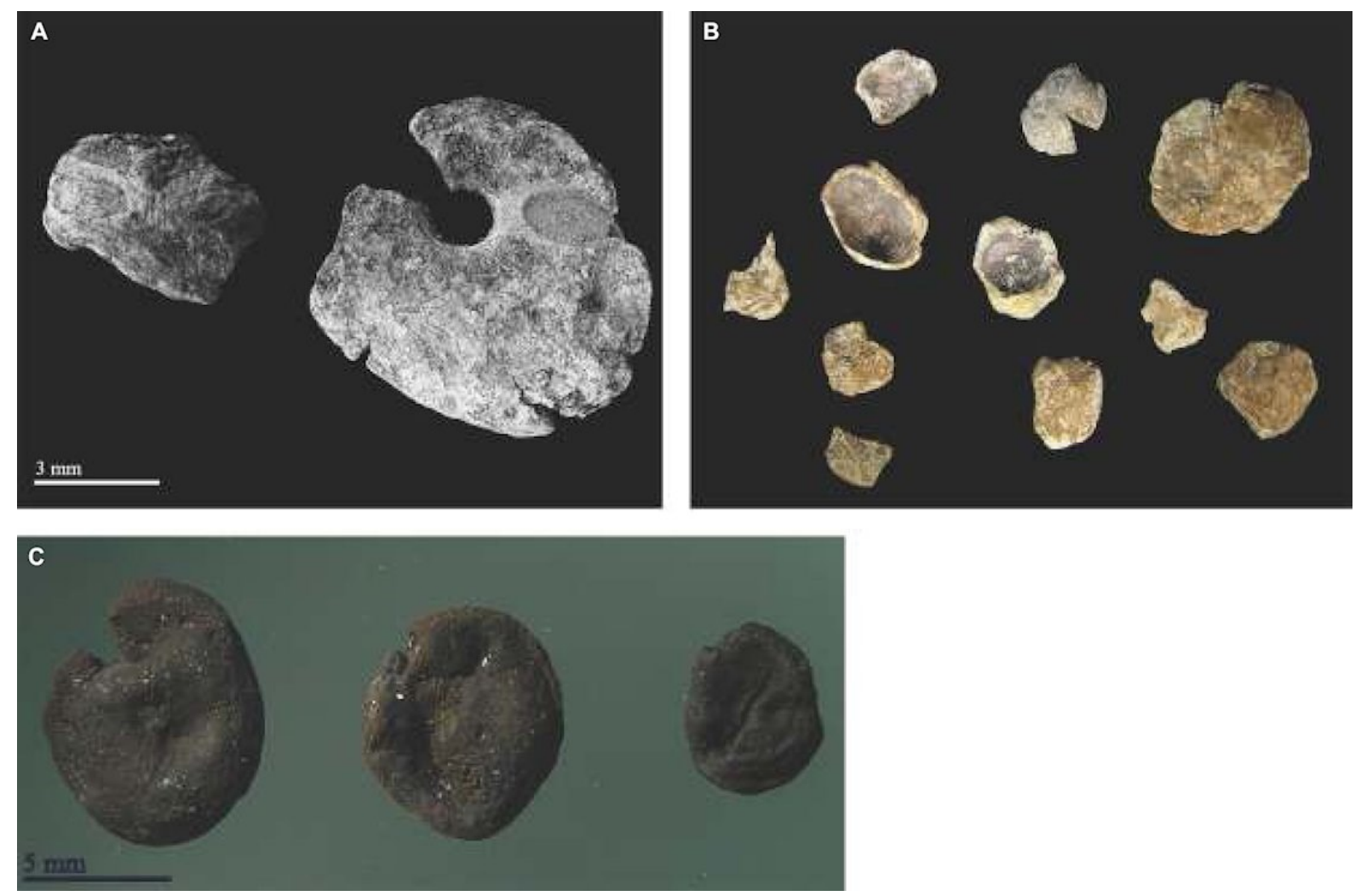

Figure 3: E. ferox seed remains from GBY: (A) Fox nut (E. ferox, GBY Layer II-6 Level 1), seed coat fragments easily identified by their characteristic attachment scar (hilum) close to the germination aperture (appears in the right fragment) (SEM); (B) Fox nut (E. ferox, GBY Layer II-6 Level 1), seed coat fragments, eight showing the convex outer side and three the concave inner side; (C) Fox nut (E. ferox, GBY Layer III-7), complete and compressed seeds. (Image credit: authors)

The prickly water-lily is an annual or perennial plant with long-petiole leaves whose large rounded blades (normally up to 1.3 and occasionally $2.4 \mathrm{~m}$ in diameter) float on the water surface. The long petiole and veins that protrude from the bottom of the blade are densely covered with sharp prickles. The rhizome is sunk deep in the ground with the help of groups of thick and fleshy roots. The plant develops approximately 15-20 spongy fruits, each of which 
contains 30-40 nuts. When the fruit is ripe it dehisces and releases the nuts, which are covered by a mucilaginous arillus (Jha et al. 1991).

The plant grows in shallow stagnant water generally $0.3-1.5 \mathrm{~m}$ deep and at a neutral $\mathrm{pH}$. In the study region in Madhubani District, Bihar, water depths reach a maximum depth of around 3.5m. Flowering occurs in April-May and the fruits ripen and dehisce between June and August, when spherical nuts are released. The nuts have a mucilaginous arillus that holds them above the water surface for several days, after which they sink to the bottom of the water body. The plant germinates in early winter and grows with surprising speed, the biomass doubling each month from January to July. The maximal biomass found in a pond in India was $1.7 \mathrm{~kg} / \mathrm{m}^{2}$ fresh weight in July. Temperature has a profound effect on the rate of biomass production (Jha et al. 1991).

As regards their nutritional value, E. ferox nuts contain $12.8 \%$ moisture, $9.7 \%$ protein, $0.1 \%$ fat, $0.5 \%$ minerals, $76.9 \%$ carbohydrates, $0.9 \%$ phosphorus, $0.02 \%$ calcium and $1.4 \mathrm{mg} / 100 \mathrm{~g}$ carotene. The calorific value is $362 \mathrm{kcal} / 100 \mathrm{~g}$ for raw $E$. ferox and $328 \mathrm{kcal} / 100 \mathrm{~g}$ for popped nuts (see below for description of the processing techniques of these nuts). Popped nuts are comparable with staple food such as wheat and rice. The essential amino acid indices (EAAI) in the raw and popped parts of edible E. ferox nuts are $93 \%$ and $89 \%$, respectively. These are higher than the values for rice (83\%), wheat (65\%), Bengal grain $(81.55 \%)$, soya bean $(85.6 \%)$, amaranth $(57.5 \%)$, human milk $(81.55 \%)$, cow's milk (88.8\%), fish $(89.2 \%)$ and mutton $(87.24 \%)$ (Jha et al. 1991; Jha and Barat 2003; Ghosh and Santra 2003). E. ferox nuts are superior to dry fruits such as almonds, walnuts, coconuts and cashew nuts in terms of sugar, protein, ascorbic acid and phenol content (Jha et al. 1991; Jha and Barat 2003; Ghosh and Santra 2003).

E. ferox was present in Europe in the geological past, becoming extinct during the Quaternary (Simpson1936; Miki 1960; Soboleweska 1970; Jha et al. 1991; Ghosh and Santra 2003). Fossil nuts of this species have been reported from the Pleistocene in Poland (Soboleweska 1970) and England (Gibbard et al. 1996), and from the Oligocene in Scotland (Simpson 1936). Evidence of E. ferox is also noted in Tertiary deposits in Kolkata, India (Jha et al. 1991; Ghosh and Santra 2003). Nuts of several extinct fossil Euryale species, including $E$. europaea Weber, E. lissa Reid and E. nodulosa Reid, were found in geological layers in Europe and Japan (Miki 1960). At present, E. ferox is the only surviving 
species of the genus, which is the only recent genus of the subfamily Euryaloideae.

\section{Materials and Methods}

The methodology for calculating the number of Euryale ferox and Trapa natans nuts in the archaeological record at GBY was as follows:

E. ferox - calculation of nut numbers: The number of complete nuts (Table 1) was calculated for each excavated unit by estimating the number of fragments that could be conjoined to form a single nut coat. When this estimate suggested the presence of more than one nut, the number was rounded up to two, and so forth. However, some units yielded fragments including characteristic structures such as the attachment scar (hilum) or germination aperture of the nuts. In such cases, their number was compared to the estimated value derived from the conjoined fragments and the higher value was considered to represent the minimum number of complete nuts in the assemblage.

T. natans - calculation of nut numbers: The nuts of $T$. natans (Table 1 ) consist of a single nut enclosed within a bony calyx. The calyx bears four lateral spines, a typical depression at the base and an aperture surrounded by an extended rim at the tip. Most of the $T$. natans remains from GBY are fragments of the nut wall, while others are spines, apertures or bases. Hence, the number of nuts in each layer/level was calculated by estimating the number of fragments that could be conjoined to form a single nut wall. In addition, for layers/levels that also contained spines, apertures and bases, each structure was counted separately and the number of spines was divided by four. In such cases, as for $E$. ferox, their number was compared to the estimated value derived from the conjoined fragments and the higher value was considered to represent the minimum number of complete nuts in the assemblage. 
Table 1: Nuts and shell fragments of E. ferox and T. natans at GBY (updated from previous work). Apart from layers/levels noted below, pitted stones (without botanical remains) were also found in Layer V-4: N=1; Layer V-5: N=4; Jordan Bank

(Layers V-5 and V-6 excavated together under water): $\mathrm{N}=7+2$ anvils; Layer II-6 Level $4 \mathrm{~b}$ : $\mathrm{N}=26+2$ anvils

\section{Euryale ferox}

\begin{tabular}{|c|c|c|c|c|c|c|c|c|}
\hline \multirow[b]{2}{*}{ Layer } & & & & & & & \multirow{2}{*}{$\begin{array}{c}\text { Pitted } \\
\text { stones/ } \\
\text { anvils }\end{array}$} & \multirow{2}{*}{$\begin{array}{l}\text { Approximate } \\
\text { sample } \\
\text { volume (in } \\
\text { litres) }\end{array}$} \\
\hline & $\begin{array}{c}\text { No. of } \\
\text { fragments }\end{array}$ & $\begin{array}{c}\text { No. of } \\
\text { complete } \\
\text { nuts }\end{array}$ & $\begin{array}{c}\text { Calculated } \\
\text { no. of } \\
\text { nuts }\end{array}$ & $\begin{array}{c}\text { No. of } \\
\text { fragments }\end{array}$ & $\begin{array}{c}\text { No. of } \\
\text { complete } \\
\text { nuts }\end{array}$ & $\begin{array}{c}\text { Calculated } \\
\text { no. of } \\
\text { nuts }\end{array}$ & & \\
\hline VI-2 & & & & 11 & & 3 & & 0.35 \\
\hline VI-3 & & & & 1 & & 1 & & 0.3 \\
\hline$* \mathrm{~V}-6$ & 2 & & 1 & 391 & & 51 & 3 & 374.4 \\
\hline VI-4 & & & & 59 & & 9 & & 2.2 \\
\hline VI-5 & & & & 6 & & 2 & & 0.3 \\
\hline VI-6 & & & & 7 & & 2 & & 0.8 \\
\hline$* \mid-4$ & 4 & & 1 & 176 & & 28 & & 308.75 \\
\hline $\begin{array}{l}{ }^{*} \mid-4+ \\
\text { I-5 }\end{array}$ & 16 & & 9 & 1320 & & 108 & & 1137.5 \\
\hline VI-7 & & & & 16 & & 3 & & 0.9 \\
\hline$* \mid-5$ & & & & 30 & & 4 & & 190 \\
\hline VI-8 & & & & 6 & & 1 & & 0.7 \\
\hline${ }^{*} I I-2$ & 69 & & 46 & 72 & & 6 & & 879.1 \\
\hline VI-9 & & & & 2 & & 1 & & 0 \\
\hline
\end{tabular}




\begin{tabular}{|c|c|c|c|c|c|c|c|}
\hline $\begin{array}{l}{ }^{*} \| I- \\
2 / 3\end{array}$ & 27 & & 17 & 63 & 6 & 2 & 341.25 \\
\hline II-3 & 8 & & 3 & 15 & 2 & & 117.5 \\
\hline VI-10 & 9 & & 3 & 7 & 2 & & 0.8 \\
\hline II-3/4 & & & & 3 & 1 & & 8.75 \\
\hline ||-4 & 8 & & 4 & 16 & 2 & & 291.25 \\
\hline II-4/5 & & & & 13 & 2 & & 151.25 \\
\hline *II-5 & 752 & & 222 & 920 & 69 & 3 & 4635 \\
\hline VI-12 & & & 1 & 3 & 1 & & 1.5 \\
\hline $\begin{array}{l}3 \|- \\
5 / 6\end{array}$ & 58 & & 25 & 38 & 5 & 1 & 751.97 \\
\hline $\begin{array}{l}\text { NII-6 } \\
\text { L1 }\end{array}$ & 654 & 2 & 204 & 414 & 27 & $23 / 8$ & 4333.75 \\
\hline $\begin{array}{l}\text { l11-6 } \\
\text { L2 }\end{array}$ & 128 & 1 & 45 & 60 & 4 & $228 / 8$ & 1263.75 \\
\hline $\begin{array}{l}\text { ll-6 } \\
\text { L3 }\end{array}$ & 15 & & 8 & 1 & 1 & $12 / 5$ & 501.25 \\
\hline $\begin{array}{l}\text { ll-6 } \\
\text { L4 }\end{array}$ & 9 & & 5 & 8 & 1 & $37 / 7$ & 653.75 \\
\hline $\begin{array}{l}\text { *1I-6 } \\
\text { L5 }\end{array}$ & 4 & & 1 & 0 & 0 & $7 / 1$ & 107.5 \\
\hline $\begin{array}{l}\text { *II-6 } \\
\text { L6 }\end{array}$ & & & & 0 & 0 & $32 / 6$ & 81.25 \\
\hline
\end{tabular}




\begin{tabular}{|c|c|c|c|c|c|c|c|c|}
\hline $\begin{array}{l}{ }^{*} I 1-6 \\
\text { L7 }\end{array}$ & 131 & & 18 & 4 & & 1 & $28 / 5$ & 488.6 \\
\hline IV-6 & & & & 1 & & 1 & & 5.74 \\
\hline II-7 & & & & 33 & 1 & 7 & & 10.71 \\
\hline IV-7 & & & & 30 & & 9 & & 10.8 \\
\hline II-8 & & & & 16 & & 2 & & 9.36 \\
\hline II-9 & 3 & & 1 & 61 & & 11 & & 2.34 \\
\hline II-10 & 5 & & 3 & 20 & & 5 & & 0.99 \\
\hline II-11 & & & & 18 & & 5 & & 2.5 \\
\hline III-4 & & & & 4 & & 1 & & 3.24 \\
\hline III-5 & 8 & 1 & 5 & 0 & & 0 & & 3.96 \\
\hline III-6 & & & & 3 & & 1 & & 2.16 \\
\hline III-7 & 123 & 3 & 19 & 27 & & 26 & & 9.72 \\
\hline III-9 & & & & 2 & & 2 & & 1.44 \\
\hline Total & 2033 & 7 & 641 & 3877 & 1 & 413 & & 16687.38 \\
\hline
\end{tabular}




\section{The Context of E. ferox Remains at GBY}

The identification of complete and fragmentary remains of $E$. ferox within waterlogged archaeological horizons at GBY necessitated study of the site's taphonomy, with particular attention to the degree to which hominins were the agents responsible for the accumulation, spatial patterning and physical condition of the remains.

Examination of site formation processes at GBY indicates that the archaeological horizons were sealed rapidly, demonstrating a high integrity of preservation and an excellent context for studies of spatial patterning (Alperson-Afil et al. 2009). Observations from several archaeological horizons at the site may be summarised as follows:

a. Intact embryos and faecal pellets of two extinct freshwater molluscs, Viviparus apameae galileae and Bellamya sp. (Ashkenazi et al. 2009) were present, together with packstone of the molluscs (Sharon and Goren-Inbar 1999; Goren-Inbar and Sharon 2006; Rabinovich et al. 2012), in a single layer at GBY in association with thousands of stone artefacts and fossil mammal bones. Trampling and other post-depositional agents would not have left the embryos and faecal pellets intact.

b. The record of organic material comprises wood, bark, seeds and fruits (Goren-Inbar et al. 2002b; Melamed 2003), signifying minimal exposure to atmospheric conditions and hence minimal presence of bacterial activity that would have destroyed the anatomical structure and resulted in decomposition.

c. The preservation of medium-sized and large mammal bones at the site is excellent and hominin-induced markings (cut marks, percussion marks and hack marks) are discernible on them (Rabinovich et al. 2008; 2012). Experimental studies of faunal remains support these observations (Gaudzinski-Windheuser et al. 2010; Rabinovich et al. 2012). Further evidence includes the presence of conjoinable bones in some levels and layers, indicating that taphonomically the bones underwent minimal reorganisation (Goren-Inbar et al. 1994).

d. Fish remains at the site demonstrated differential preservation, being deposited either as a natural death assemblage (Zohar and Biton 2011) or in association with remains of hominin activities (Alperson-Afil et al. 2009). 
e. The presence and spatial clustering of flint, basalt and limestone microartefacts is a clear indication that taphonomic processes at GBY had a minimal effect on archaeological horizons. The unique record of the burned flint component (microartefacts) viewed as 'phantom hearths' further confirms the excellent preservation of archaeological and associated materials/features. In these cases, spatial patterning reflects the time of abandonment. The lack of sedimentary obstacles, linear deposition or winnowing, and the spatial association of finds (Alperson-Afil and Goren-Inbar 2010), emphasise the absence of discernible taphonomic processes.

Table 1 presents the occurrence and frequencies of the two types of water nuts at GBY. Both $E$. ferox and $T$. natans nuts are present in both archaeological horizons and geological layers, the latter being devoid of lithic artefacts. The marked difference between archaeological and geological layers in quantities of $E$. ferox and $T$. natans arises primarily from different sampling strategies. Geological layers were minimally sampled along the walls of the trenches (Trenches II-VI) as compared to the extensive studies conducted on archaeological horizons. Within geological layers, there are differences in the occurrences of the two types of nuts. In Layer III-7, both nuts are well represented with $E$. ferox predominating. In other layers, $T$. natans is the dominant seed, with its highest occurrence being in Layer II-9, a gray mud sediment characteristically deposited under the highest water column and which represents the deepest part of the paleo-lake. Sedimentologically, a group of geological layers (Layers II-9, II-10, II-11, III-7) with a high occurrence of $T$. natans represent coquinas. The absence of lithics in these layers does not necessarily mean that they are archaeologically sterile. Although this may appear to be a contradiction, our experience at the site leads us to suggest that layers that are apparently archaeologically sterile may bear artefacts further along the strike, beyond the boundaries of excavated areas. In some cases (e.g. Layer II-12 in Goren-Inbar et al. 2002b, 81), an isolated microartefact indicated the presence of an as yet unknown and unexcavated archaeological horizon. Thus, the presence of seeds in archaeologically sterile layers may be explained in two ways; as a natural occurrence or as a result of human behaviour. In the absence of further excavations, neither possibility can be confirmed.

Remains of $E$. ferox are extremely abundant in the rich archaeological horizons (Table 1 , rows marked by $*$ ). They occur in varying frequencies in these layers, as well as within the archaeological complex of Layer II-6. Hominin activities 
varied significantly between the 15 rich archaeological horizons, as reflected by differences in the presence and frequencies of finds (stone artefacts, fossil bones and organic remains). Here, we propose the hypothesis that the spatial patterning, physical condition and concentration of E. ferox nut fragments at the site is the result of intentional hominin gathering and processing rather than of natural factors. The key evidence for this is the co-occurrence of nuts and their fragments with phantom hearths and pitted stones (Goren-Inbar et al. 2002a), which occur in 10 of the 15 archaeological strata containing $E$. ferox remains (Figure 3). One possible use of the pitted stones was as 'anvils' for popping nuts. On the basis of ethnographic parallels discussed below, we believe that the association of many $E$. ferox fragments with pitted stones and phantom hearths is an indication of intentional roasting followed by popping to extract the nut from its hard shell and exploit its maximum nutritive value (Jha and Barat 2003). A new type of anvil, a component of the percussive tool assemblage, was recently identified at GBY (Goren-Inbar et al. in prep). These passive (dormant) percussive tools (de Beaune 2000) consist of thin natural basalt slabs with two flat surfaces that are sometimes broken, probably as a result of use. This is the first report of such thin anvils from an Acheulian site. They are characterised by the presence of pits and other abrasive damage marks on one or both flat surfaces and sometimes on the thin edges. Such anvils are not found at the lake's edge but were selected for their particular morphology and specific characteristics (e.g., hardness and non-vesicular nature) and brought from exposures of basalt flows that are currently unknown in the vicinity of the site. The total number of these anvils at GBY is 36, 26 of which are pitted. Along with pitted stones (the latter primarily of basalt but also of limestone), these anvils occur diachronically throughout the cultural sequence of the site (Table 1). The same is true for pitted stones, although their availability was most probably more extensive since their morphology is more varied (Goren-Inbar et al.2002a). Together, these percussive tools form the bulk of the tools that we propose were used to pop theE. ferox seeds and crack other types of nuts. 

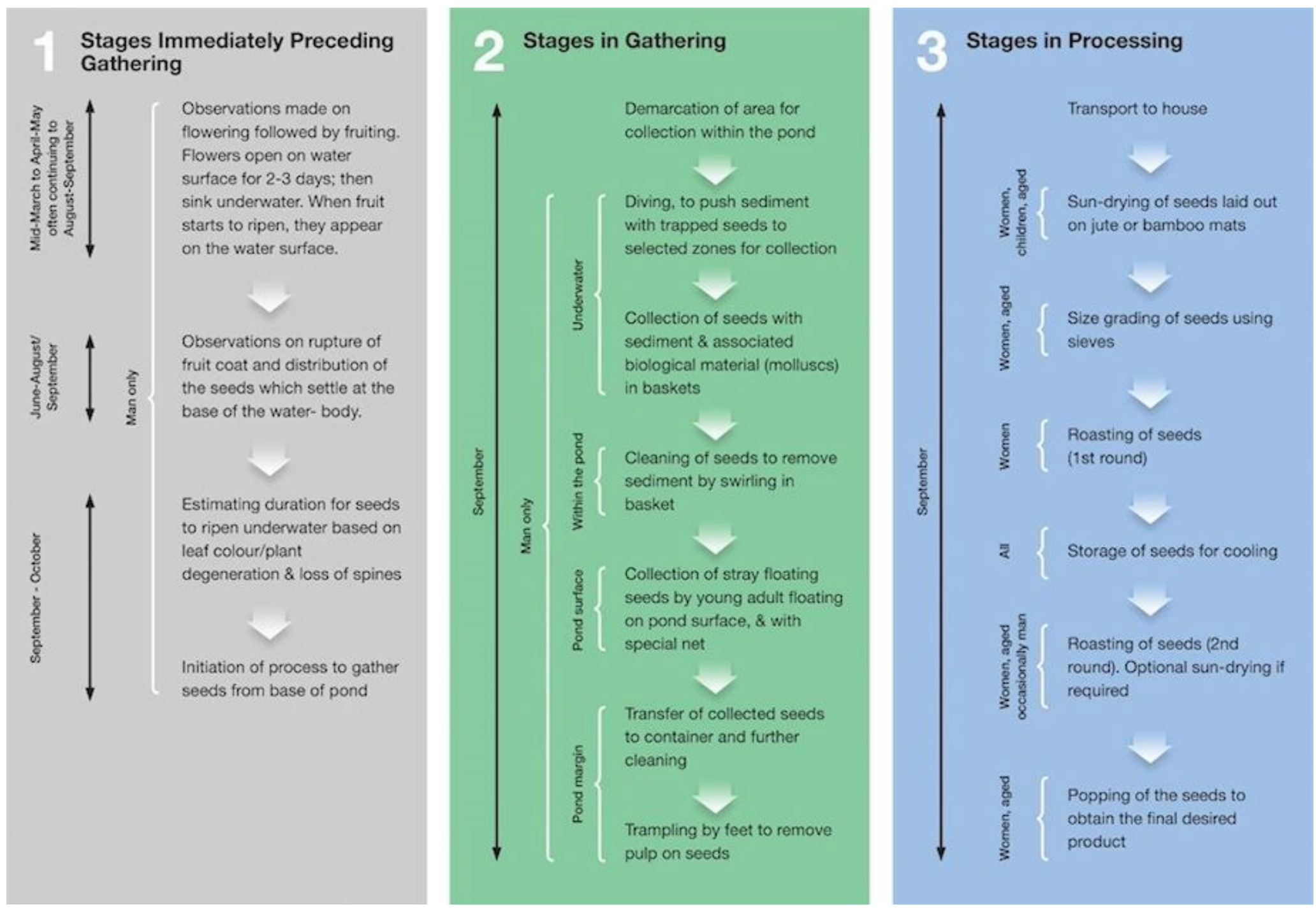

Figure 4: Flow charts highlighting the main events in the gathering and processing of E. ferox (locally called Makhana) based on our ethnographic observations in Madhubani District, Bihar and summarised from published literature (Jha et al. 1991; 2003; Mishra et al.2003; Mandal et al. 2010). (Image credit: authors) 


\section{Traditional Modes of Exploitation of $E$. ferox in India}

Here, we draw on ethnographic analogies citing traditional methods of $E$. ferox exploitation in the water bodies of northern Bihar, India, where planned sequential procedures and decision-making strategies are employed by local communities in collecting and processing E. ferox nuts (Jha et al. 1991; 2003; Jha and Barat 2003; Ahmad and Singh 2003; Goswami 2003; Khan and Halim 2003; Mishra et al. 2003; Singh 2003; Jain et al. 2010; Jain et al. 2011; Mandal et al. 2010; Singh and Singh 2011). The procedures adopted in Bihar imply an excellent knowledge of the environment and seasonality in relation to the plants' life cycle (Jha et al. 1991) (Figure 4). Important to note here is the fact that the prickles/spines on mature fruits make them very difficult to harvest with bare hands. Once the mature fruits burst, the seeds float near the leaves and then sink to the base of the pond, from where they are collected. Thus, a structured sequential process has been devised for gathering and processing the nuts, which has been discussed in the literature (Jha et al. 1991; 2003; Ahmad and Singh 2003; Mishra et al. 2003; Singh 2003; Mandal et al. 2010) and documented as part of this study (see Figures 5-8).

Based on these sources of information, we note that gathering is carried out by adult males assisted by a few adolescent boys, with a division of activities that is related to age and/or experience. The process can be summarised as follows: 1 ) the equipment required (bamboo collection baskets of various types) is organised; 2) bamboo poles fixed to the base of the pond serve as guides to demarcate spaces selected for underwater gathering of the nuts and are shifted as collection proceeds across the water body; 3 ) adults repeatedly dive underwater to collect nuts that have sunk to the pond bed, at the base of the plant; 4) the nuts are scooped into bamboo baskets (sieves); 5) in larger ponds the nuts are scooped into a large cane basket and given a preliminary cleaning underwater by repeated rotation; 6) an adolescent (inexperienced in diving) floats on the water surface with the aid of pitchers or jerry cans and employs a sieve to collect stray nuts that float to the surface; 7) the nuts brought to the shore are cleaned by trampling to remove roots, plant matter and associated molluscs (Jha et al. 1991; 2003; Ahmad and Singh 2003; Mishra et al. 2003; Singh 2003; Mandal et al. 2010). Children actively participate in gathering molluscs, crabs and other plants that are associated with the E. ferox roots and are washed up on the shore during the gathering and cleaning procedure. 

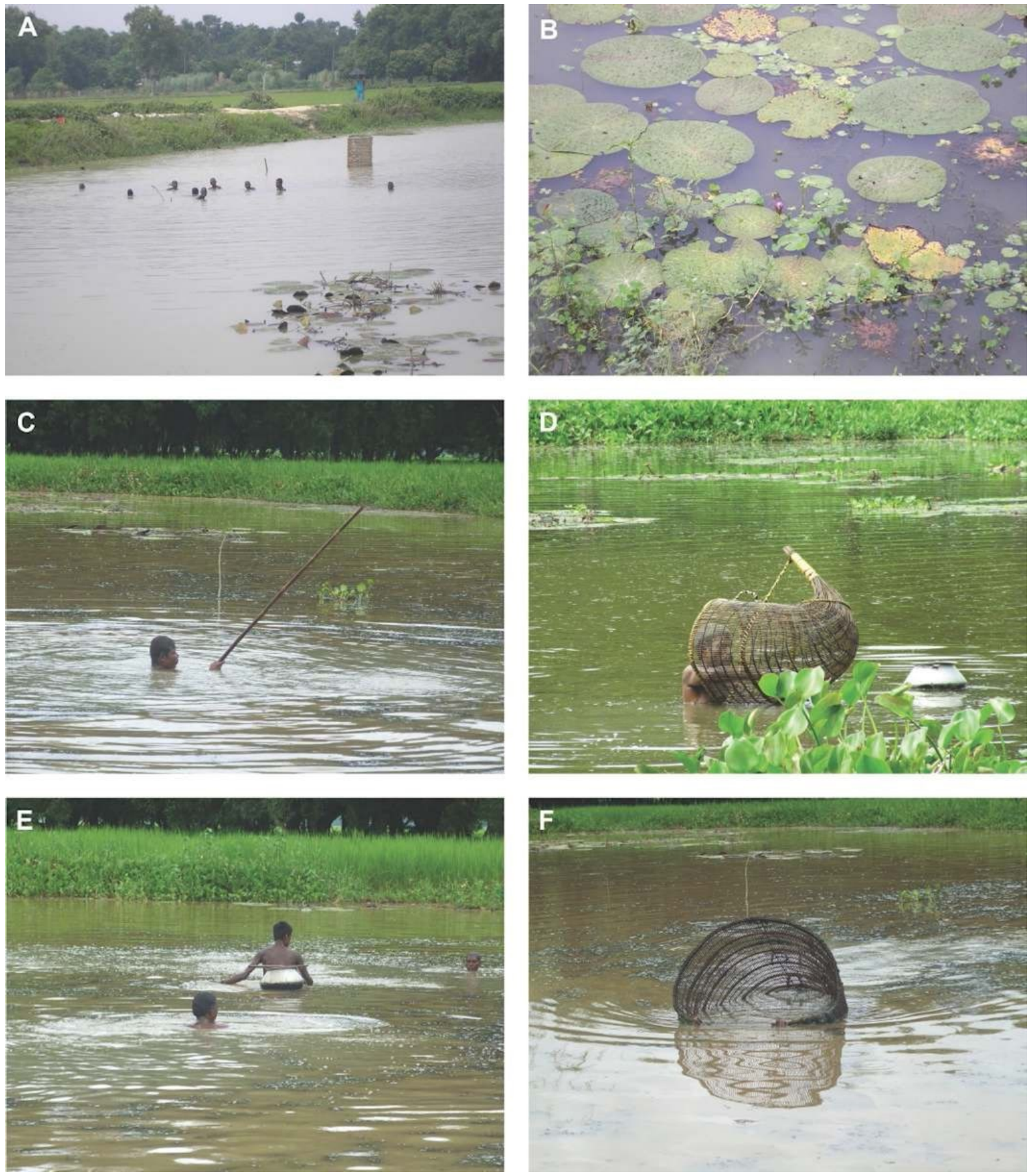

Figure 5: Procedures involved in the collection of E. ferox nuts, Madhubani District, Bihar, India; (A) General view of men of the fishing community involved in the gathering of E. ferox (Makhana) nuts; note one type of collecting basket in the background; (B) Close-up of E. ferox, showing the flower and characteristic leaves; (C) View of a diver manipulating a bamboo pole that aids in demarcating areas selected for underwater gathering of E. ferox nuts; (D) Diver surfacing after gathering $E$. ferox nuts using a special type of basket (Gaanja), with an aluminum pot also used for collection; (E) Adolescent boy collecting stray nuts that rise to the water surface from the pond bed during collection; (F) Divers (underwater) manipulating a large basket (Auka) in which nuts are collected. Note the two hands at the edge of the basket. (Image credit: authors) 

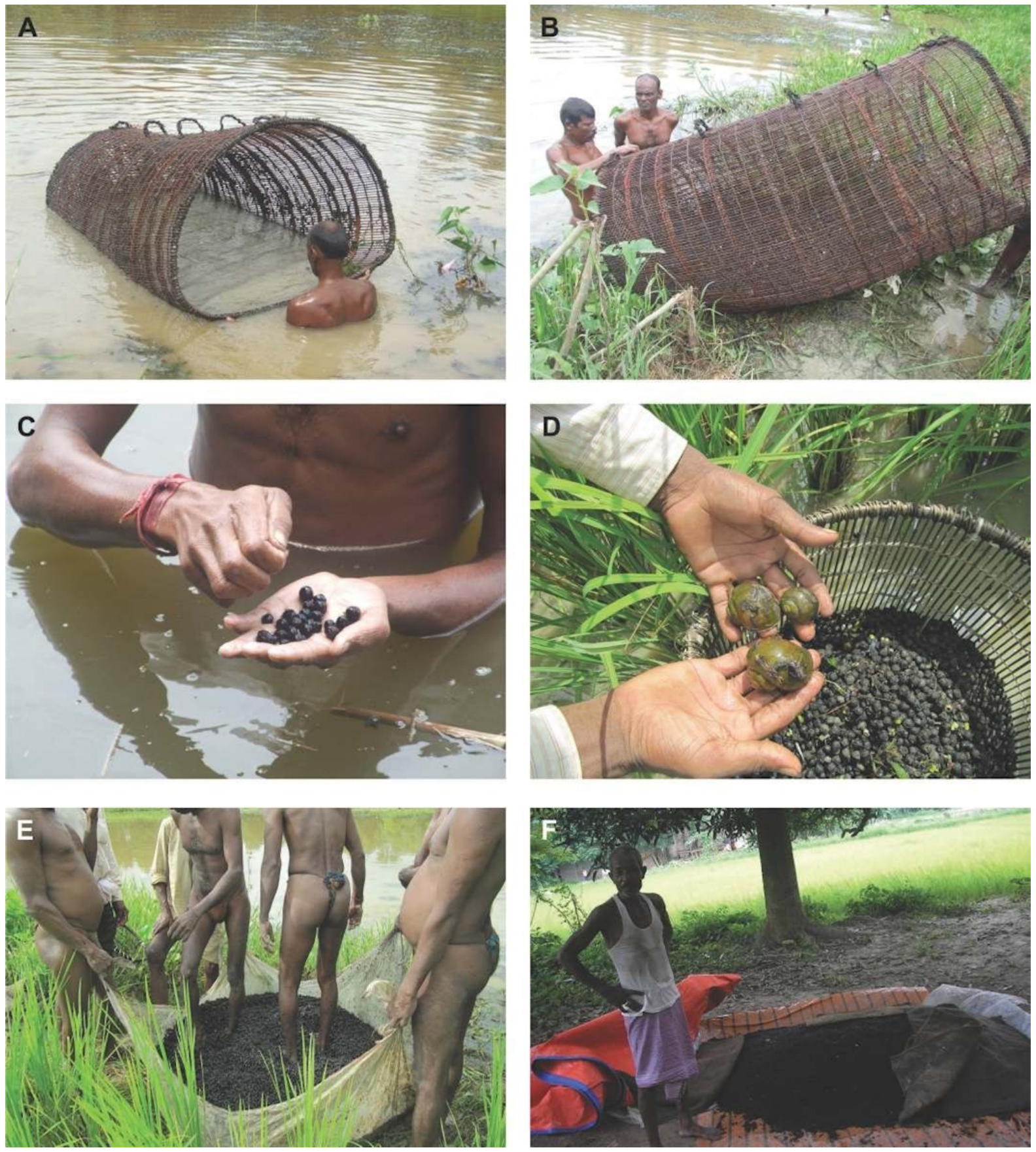

Figure 6: Procedures involved in the collection of E. ferox nuts, Madhubani District, Bihar, India: (A) Diver with the basket that is rotated within water to cleanse the nuts; (B) Divers bring the basket to the shore to complete the process of cleansing the nuts; (C) Close-up of the collected nuts; (D) View of the E. ferox nuts with associated molluscs; (E) Trampling helps remove the pulp; F) A mound of nuts piled up near the water body ready for transport to the village. (Image credit: authors) 

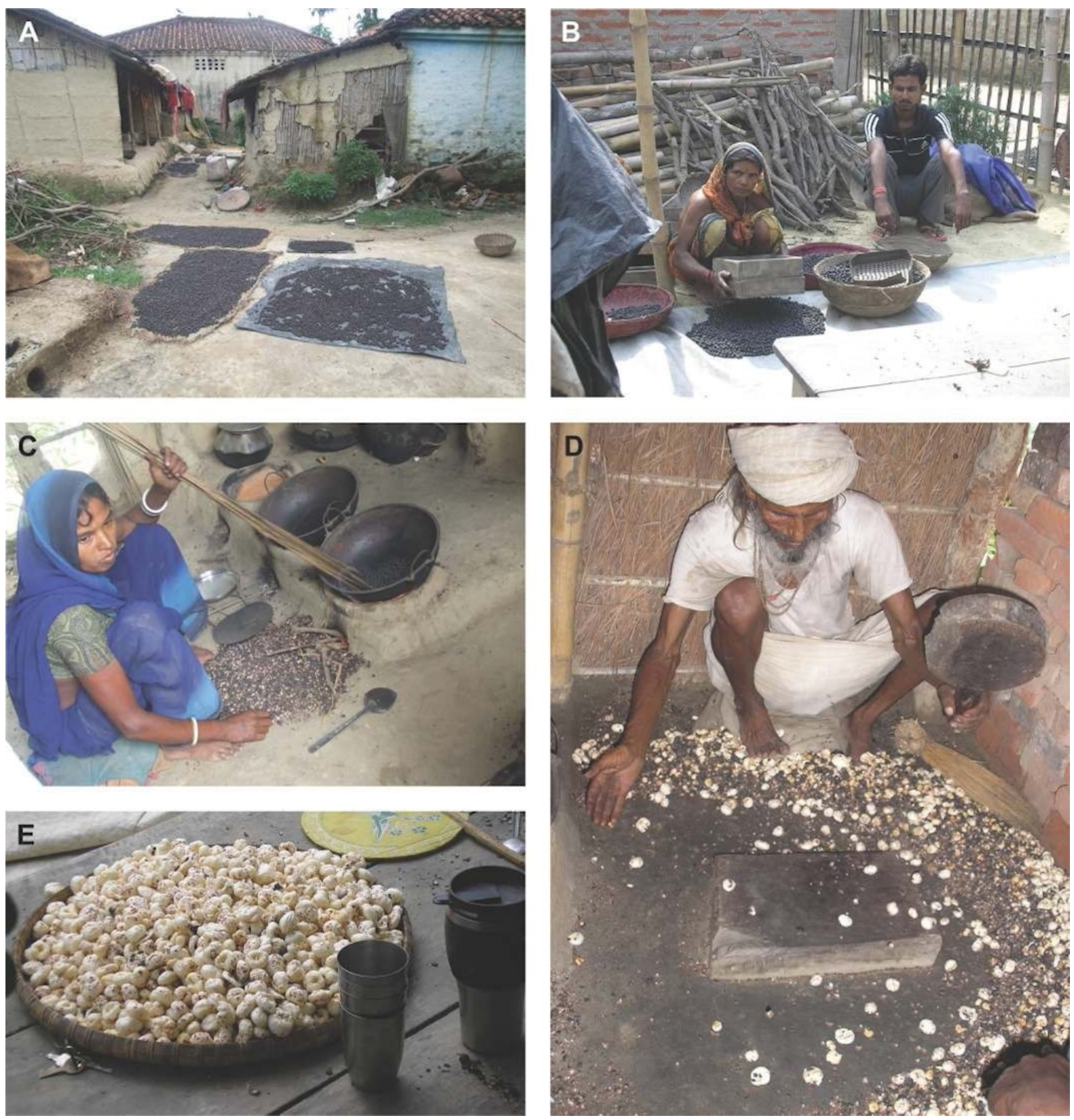

Figure 7: Procedures involved in processing of E. ferox nuts, Madhubani District, Bihar, India: (A) E. ferox nuts are spread out to dry in the sun in the village; (B) The nuts are sorted into differing size ranges using sieves of different dimensions; (C) The nuts are roasted and stirred using bamboo sticks; (D) Popping of the $E$. ferox nuts immediately after roasting; note the wooden anvil and hammer; $(E)$ View of the popped E. ferox nuts ready to be eaten. (Image credit: authors) 


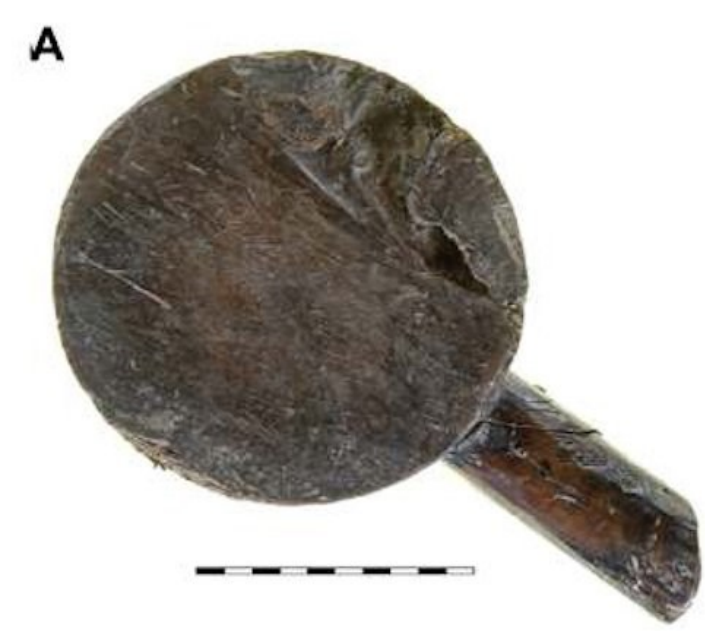

C

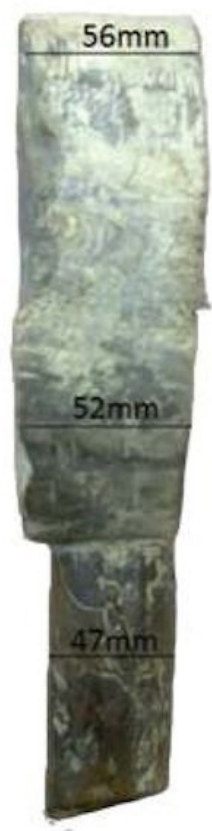

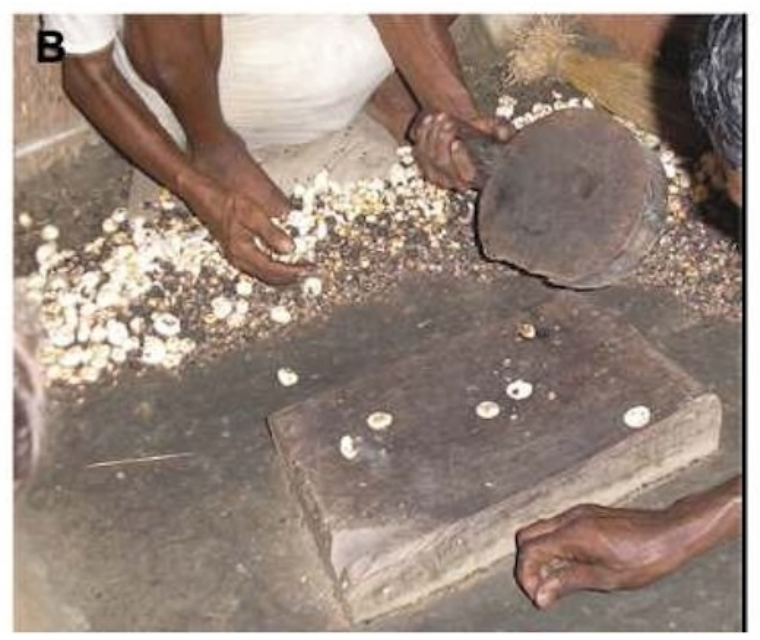

D

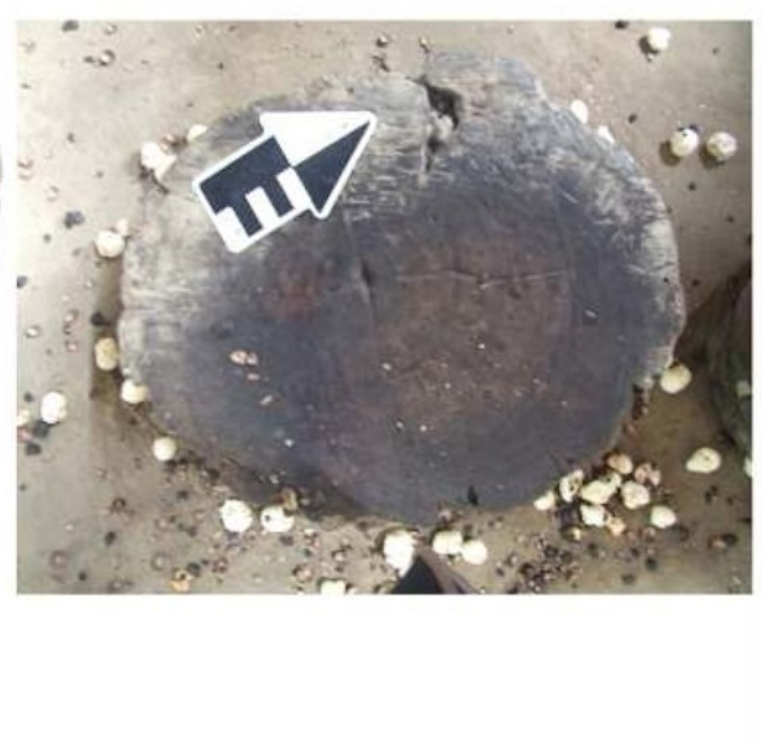

Figure 8: Hammer and anvil used for popping the dried and roasted E. ferox nuts in traditional practices in Madhubani District, Bihar, India: (A) General view of a wooden hammer (Thaapi) (photograph: Gabi Laron); (B) A wooden anvil (Aphara); (C) Measurements of a typical hammer; (D) Close-up of an anvil used for popping $E$. ferox nuts. (Image credit: authors) 


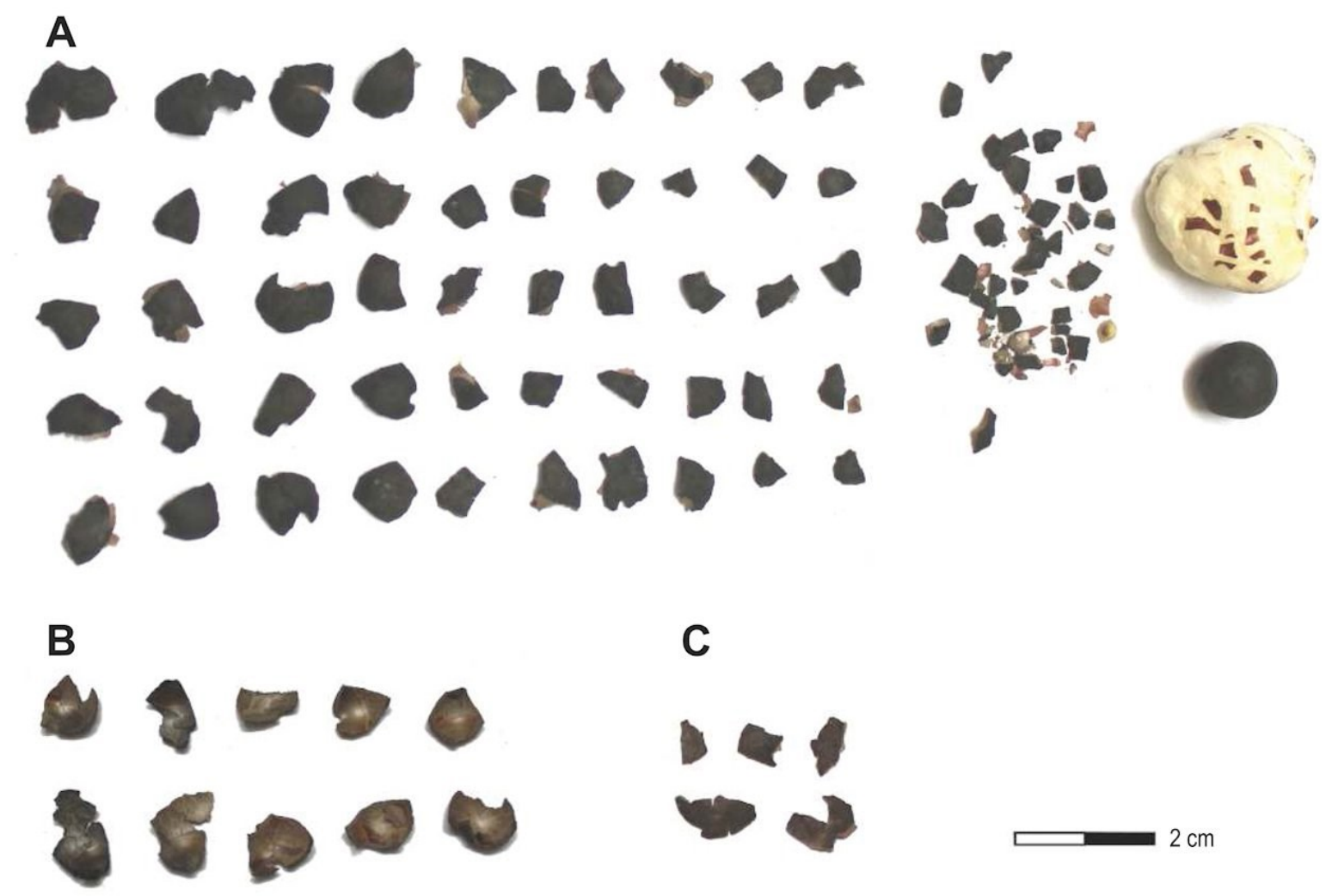

Figure 9: Debris of $E$. ferox nuts after popping: (A) A handful of nuts (eight in number) generally popped together ( $N=50$ fragments varying from $1 \mathrm{~mm}$ to $1 \mathrm{~cm}$, the rest being $<1 \mathrm{~mm}$ ). At the top right of the image, note a complete roasted nut of the same size group (diameter $=11.49 \mathrm{~mm}$ ) as well as the final popped Makhana; (B) Close-up of nut fragments showing inner concave side; (C) One roasted Makhana nut ( $\mathrm{N}=5$ fragments) after popping. (Image credit: authors)

Processing the nuts in the village comprises size sorting the nuts using a set of sieves, several stages of sun-drying and roasting on a wood fire and lastly popping, which results in the final nutritious product (Jhaet al. 1991; 2003; Figures 7-9). The procedure of popping $E$. ferox seeds is widely used in Bihar and involves drying followed by at least two cycles of roasting the nuts. The nuts are then placed on a wooden anvil (around $60-70 \mathrm{~cm}$ in diameter) and struck with a wooden mallet-like hammer (around $17-27 \mathrm{~cm}$ in diameter) (Figures 7-8). These tools are purpose-built and are carved from the heartwood of Dalbergia sisoo, Acacia lenticularis and Shorea robusta (Jha et al. 2003) (Figures 7-8). Popping is a process whereby superheated vapour is created within the conditioned nut by heating the moisture contained within, following which the pressure is suddenly released, resulting in expansion of the volume of the kernel. Popping the $E$. ferox seeds by traditional methods increases the concentration of micronutrients per unit weight. 
A distinct gender-based division of labour is observed. Activities within the pond/lake are male dominated, while those involving drying, cleaning, roasting and popping the seeds are largely the preserve of women, aided by children and elderly men.

It has been mentioned that the prickles/spines on the outer surface of mature fruits makes them difficult to harvest with bare hands, a problem resolved in the study region by collection after the fruits burst and sink to the bed of the pond. In Bangladesh, however, this species is harvested using boats and long-handled curved knives in order to cut the pedicle underwater (Khan and Halim 2003) and the pulpy aril and seeds are eaten, while the endosperm of the seeds is consumed raw or roasted (Khan and Halim 2003). In parts of north-east India, such as Assam, the edible seeds are eaten raw or in rare cases processed further (Goswami 2003, 34). In Manipur, the leaf petioles and seeds are eaten raw or boiled (Singh 2003, 10-11). Elsewhere in this state, the tender leaves, seed aril and fruit skin are also consumed after removal of the prickles by fire or otherwise, as is the mature leaf petiole after removal of the spines (Singh 2003, 11). It is also noted that the seeds are eaten raw after roasting in the sand and dehusking (as quoted in Singh 2003, 11). In several regions here, ripe seeds may also be eaten raw (Jain et al. 2010, 64; Jain et al. 2011) or used in a range of traditional food preparations for dietary or medicinal purposes. Others (Singh and Singh2011) note that the immature fruits are consumed after boiling while the ripe ones are eaten fresh. In all cases, attention is paid to seasonality in harvesting parts of the plant (Jain et al. 2010, 66). 


\section{Significance in Terms of $E$. ferox Exploitation at GBY}

The Indian record of $E$. ferox seed consumption indicates that there are several ways to harvest and process E. ferox nuts. Clearly, the major difficulty to be overcome is the presence of prickles/spines that make processing the fruit difficult. Further difficulties involve collection of seeds after the fruit bursts. The Bihar method described here overcomes both of these problems through adoption of underwater collection procedures. Key points emerging from investigation of traditional methods from Bihar in the context of the $E$. ferox remains from GBY are summarised as follows: a) gathering of $E$. ferox seeds takes place after they ripen and sink to the bed of the water body; b) gathering by diving is a necessity, as the plants grow in still waters and seeds are not washed to the edges of the water body; c) the work necessitates observation of the lifecycle of the plant and of the prime time for gathering seeds; d) drying and popping seeds was done at a distance from the water body, where fire and dry land facilitated later stages of processing; e) roasting and popping are both procedures requiring the technology of fire and that of anvils and hammers; and f) a well-established division of labour was associated with each stage of gathering and processing.

Different methods of $E$. ferox consumption are cited here, showing that the seeds are a highly valuable component in the diet of wetland communities. It is clear from literature and our own data that common processing methods of $E$. ferox seeds in India are those that include the use of fire. Clearly, the prickly nature of the plant parts is an important trait that local communities have to consider and overcome. We believe that the traditional ethnobotanical procedures involved in the gathering and multistage processing of $E$. ferox in Bihar are instructive parallels for the interpretation of the GBY archaeological data. Thus, the archaeological record of GBY, which includes the use of fire and the presence of pitted stones, anvils and hammerstones in association with $E$. ferox seeds, strongly supports the use of analogies with traditional modes of gathering and processing, such as that practiced by communities in Bihar. Studies of the GBY archaeological record provides information on the cooccurrence of a range of finds that may be compared with the ethnographic data. 1) In each of the archaeologically rich horizons there were spatial concentrations of burned flint microartefacts. Analysis of these concentrations suggests the presence of phantom hearths, the earliest evidence for the control 
and continual use of fire in western Eurasia (Alperson-Afil and GorenInbar 2010). High-resolution data from excavations enables estimation of the size of these hearths, which were around $0.49 \mathrm{~m}$ long and $0.35 \mathrm{~m}$ wide (AlpersonAfil and Goren-Inbar 2010, 74, table 4.1). 2) Pitted stones and hammerstones, as well as the newly identified thin basalt anvils, were also found in each of these horizons (Figure 10). 3) In all archaeological horizons, remains of $T$. natans and E. ferox were discovered as well. The pristine taphonomic context of the archaeological horizons at GBY, along with the significant patterns of association noted between various find categories discussed above, provide a background for our discussions of the spatial patterning of past activities. Spatial analysis of these associations and analyses of Layer II- 6 Levels 2 and 6 provide further insight into the proximity of hearths and pitted stones (on both blanks and blocks) (Table 1; Alperson-Afil and Goren-Inbar 2010, 91, figs 4.8, 4.9; Alperson-Afil et al. 2009, 1678, fig. 2). This correlation of nuts, phantom hearths and pitted stones at GBY leads us to suggest that some key aspects of the methods of collecting and processing noted in Bihar, which includes roasting and subsequent popping of the seeds, may be of greater relevance for the GBY data than those described from elsewhere in India. Greater precision in spatial associations between the nuts and other features in the vicinity of the paleo-lake is not possible owing to the light weight of the seeds. However, common aquatic taxa in the Upper Jordan Valley (Lake Hula), the Acheulian site of GBY and Bihar (India) (Table 2) reflect the extent of ecological similarity, despite their great biogeographical distance. The habitat and surrounding environment of paleoLake Hula was a rich and diverse Mediterranean one, as evidenced by the identification of an array of 60 edible taxa recorded at GBY (Melamed 2003, table 3), as well as a wealth of fish, crustaceans, birds and mammals. 

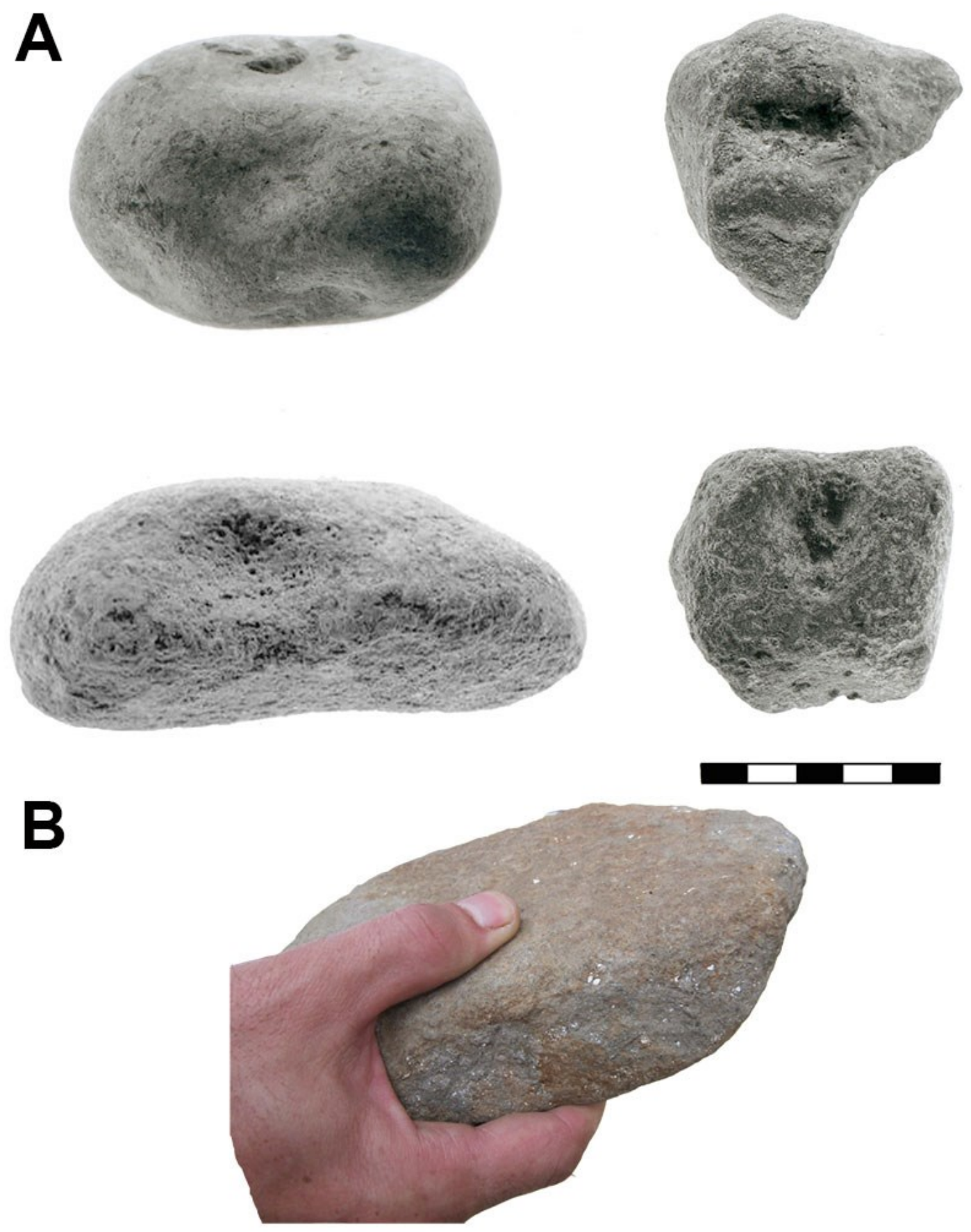

Figure 10: Anvils at the site of Gesher Benot Ya'aqov: A) Pitted anvils; B) Thin anvil. (Image credit: authors)

E. ferox grows in water bodies with water depths ranging from around $0.3 \mathrm{~m}$ to $1.5 \mathrm{~m}$, up to a maximum of around 2.5m (Jha et al. 1991; Mishra et al. 2003; Mandal et al. 2010) or up to around $3.5 \mathrm{~m}$ as noted in the study region. Although Acheulian hominins may have consumed seeds raw, this would have entailed considerable effort in harsh conditions owing to the prickly nature of the plants. With the technology enabling them to process nuts using fire, anvils and 
percussive tools, hominins could avoid the difficulties posed by exploitation of raw seeds.

The fluctuating water level of paleo-Lake Hula would have been an obstacle to adopting simpler methods for gathering nuts, in view of the plant's life cycle and the water depths and geochemistry required for its growth and survival. A desiccation scenario of fluctuating lake levels would have resulted in the death of plants, unable to regenerate as germination occurs under water. Exposure to atmospheric conditions would have resulted in the complete decomposition of the macrobotanical remains found at the site. The entire issue of organic preservation is based on anaerobic conditions (and hence inappropriate conditions for bacteria responsible for the decomposition of organic material). Irrespective of the depth of the water, hominins would have had to collect nuts from beneath the lake surface, entailing some amount of time spent under water.

It is important to note that we do not suggest that Acheulian hominins followed modes of collecting or processing that were identical to those practiced today, particularly in the case of elements dictated by modern economic conditions (use of bamboo poles to demarcate underwater areas for collecting nuts, sieves for sorting nuts for sale or even gender-based division of labour).

Such cognitive procedural abilities of planning and performance in aquatic habitats, particularly when combined with exploitation of fish (Zohar and Biton 2011) have not previously been reported for Acheulian hominins. Ethnographic analogies demonstrate that exploitation of $E$. ferox nuts is performed by communities of fishermen in water bodies that are also used for fishing (Jha et al. 1991). The most abundant fish species currently exploited in habitats associated with $E$. ferox include three families of air-breathing fish: Cyprinidae (carps), Clariidae (catfish) and Bagridae (catfish) (Table 2). At GBY, remains of Cyprinidae and Clariidae were recovered, predominantly Cyprinidae (mainly the large Barbus sp. and Barbus longiceps). Interestingly, the cyprinids remains were recovered in association with living floors excavated in Area $B$ (Table 2) (Alperson-Afil et al. 2009; Zohar and Biton 2011). The archaeological association between $E$. ferox nuts, large quantities of cyprinid remains and other cultural activities documented at GBY presents novel evidence for intensive exploitation of the aquatic fauna and flora of paleo-Lake Hula. 
Table 2: Common aquatic taxa from the Upper Jordan Valley (Lake Hula) (Danin 2004), the Acheulian site of GBY and Bihar (India) (Melamed 2003; Melamed et al. 2011). Data on fish from Goren and Ortal 1999; Zohar and Biton 2011; Montana et al. 2011. In Bihar, 35 species have a high commercial value, among which Cyprinidae and Clariidae predominate, as well as

Balitoridae. The richness of native fish species here is very high (>260 species), thus differing from that of Lake Hula similarities being at the family level (Cyprinidae predominate in both Bihar and GBY) $*$ endemic species of fish

\begin{tabular}{|c|c|c|c|c|}
\hline Aquatic flora & Ceratophyllaceae & $\begin{array}{l}\text { Ceratophyllum } \\
\text { demersum L. }\end{array}$ & $\begin{array}{l}\text { Ceratophyllum } \\
\text { demersum Salisb. }\end{array}$ & $\begin{array}{l}\text { Ceratophyllum } \\
\text { demersum Salisb. }\end{array}$ \\
\hline Aquatic flora & Nymphaeaceae & Euryale ferox Salisb. & Euryale ferox & Euryale ferox \\
\hline Aquatic flora & Nymphaeaceae & & Nuphar luteum & \\
\hline Aquatic flora & Salviniaceae & & Salvinia natans & \\
\hline Aquatic flora & Lemnaceae & Lemna minor $\mathrm{L}$. & & Lemna minor \\
\hline Aquatic flora & Potamogetonaceae & $\begin{array}{l}\text { Potamogeton } \\
\text { berchtoldii Fieber }\end{array}$ & & $\begin{array}{l}\text { Potamogeton } \\
\text { berchtoldii Fieber }\end{array}$ \\
\hline Aquatic flora & Potamogetonaceae & $\begin{array}{l}\text { Potamogeton } \\
\text { pectinatus L. }\end{array}$ & Potamogeton pectinatus L. & P. pectinatus $\mathrm{L}$. \\
\hline Aquatic flora & Potamogetonaceae & $\begin{array}{l}\text { Potamogeton } \\
\text { nodosus Poir. }\end{array}$ & & P. nodosus Poir. \\
\hline Aquatic flora & Potamogetonaceae & Potamogeton lucens L. & & P. lucens L. \\
\hline Aquatic flora & Potamogetonaceae & $\begin{array}{l}\text { Potamogeton } \\
\text { perfoliatus L. }\end{array}$ & & P. perfoliatus L. \\
\hline Aquatic flora & Lythraceae & Trapa natans L. & Trapa natans L. & Trapa natans L. \\
\hline Aquatic flora & Lentibulariaceae & Utricularia australis R.Br. & & $\begin{array}{l}\text { Utricularia } \\
\text { australis R.Br. }\end{array}$ \\
\hline
\end{tabular}




\begin{tabular}{|c|c|c|c|c|}
\hline Aquatic flora & Droseraceae & & Aldrovanda vesiculosa $\mathrm{L}$. & \\
\hline Aquatic flora & Lentibulariaceae & Utricularia gibba L. & & $\begin{array}{l}\text { Utricularia } \\
\text { gibbaL. }\end{array}$ \\
\hline & & S=11 species & $S=7$ species & $\mathrm{S}=11$ species \\
\hline Osteichthyes & Cyprinidae & $\begin{array}{l}\text { Acanthobrama } \\
\text { lissneri (Tortonese 1952) }\end{array}$ & $\begin{array}{l}\text { Acanthobrama } \\
\text { lissneri (Tortonese 1952) }\end{array}$ & $\begin{array}{l}\text { Cyprinids - } 19 \\
\text { species }\end{array}$ \\
\hline Osteichthyes & Cyprinidae & $\begin{array}{l}\text { Carasobarbus } \\
\text { canis (Valenciennes } \\
1842 \text { ) }\end{array}$ & $\begin{array}{l}\text { Carasobarbus canis } \\
\text { (Valenciennes1842) }\end{array}$ & \\
\hline Osteichthyes & Cyprinidae & $\begin{array}{l}\text { Barbus } \\
\text { longiceps (Valenciennes } \\
1842 \text { ) }\end{array}$ & $\begin{array}{l}\text { Barbus } \\
\text { longiceps(Valenciennes,1842) }\end{array}$ & \\
\hline Osteichthyes & Cyprinidae & $\begin{array}{l}\text { Capoeta } \\
\text { damascina (Valenciennes } \\
1842 \text { ) }\end{array}$ & $\begin{array}{l}\text { Capoeta } \\
\text { damascina(Valenciennes1842) }\end{array}$ & \\
\hline Osteichthyes & Cyprinidae & Garra rufa (Heckel 1843) & Garra rufa (Heckel 1843) & \\
\hline Osteichthyes & Cyprinidae & $\begin{array}{l}\text { Hemigrammocapoeta } \\
\text { nana(Heckel 1843) }\end{array}$ & $\begin{array}{l}\text { Hemigrammocapoeta } \\
\text { nana(Heckel 1843) }\end{array}$ & \\
\hline Osteichthyes & Cyprinidae & $\begin{array}{l}\text { Mirogrex } \\
\text { hulensis (Goren et al. } \\
\text { 1973) }\end{array}$ & $\begin{array}{l}\text { Mirogrex hulensis (Goren et al. } \\
\text { 1973) }\end{array}$ & \\
\hline Osteichthyes & Cyprinidae & $\begin{array}{l}\text { Pseudophoxinus } \\
\text { kervillei (Pellegrin 1911) }\end{array}$ & $\begin{array}{l}\text { Pseudophoxinus } \\
\text { kervillei (Pellegrin 1911) }\end{array}$ & \\
\hline Osteichthyes & Balitoridae & $\begin{array}{l}\text { Nemacheilus jordanicus } \\
\text { (Banarescu and Nalbant } \\
\text { 1966) }\end{array}$ & & Nemacheilus sp. \\
\hline Osteichthyes & Balitoridae & $\begin{array}{l}\text { Nemacheilus } \\
\text { panthera (Heckel 1843) }\end{array}$ & & \\
\hline
\end{tabular}




\begin{tabular}{|c|c|c|c|c|}
\hline Osteichthyes & Balitoridae & $\begin{array}{l}\text { Nun galilaeus* (Günter } \\
\text { 1864) }\end{array}$ & & \\
\hline Osteichthyes & Clariidae & $\begin{array}{l}\text { Clarias } \\
\text { gariepinus (Burchell } \\
\text { 1822) }\end{array}$ & $\begin{array}{l}\text { Clarias gariepinus (Burchell } \\
\text { 1822) }\end{array}$ & Clarias sp. \\
\hline Osteichthyes & Cyprinodontidae & $\begin{array}{l}\text { Aphanius mento (Heckel } \\
\text { 1843) }\end{array}$ & & \\
\hline Osteichthyes & Cichlidae & $\begin{array}{l}\text { Oreochromis aureus } \\
\text { (Stiendachner 1864) }\end{array}$ & $\begin{array}{l}\text { Oreochromis aureus } \\
\text { (Stiendachner 1864) }\end{array}$ & \\
\hline Osteichthyes & Cichlidae & $\begin{array}{l}\text { Sarotherodon } \\
\text { galilaeus (Artedi 1757) }\end{array}$ & $\begin{array}{l}\text { Sarotherodon galilaeus (Artedi } \\
\text { 1757) }\end{array}$ & \\
\hline Osteichthyes & Cichlidae & $\begin{array}{l}\text { Tilapia zillii (Gervais } \\
\text { 1848) }\end{array}$ & Tilapia zillii (Gervais 1848) & \\
\hline Osteichthyes & Cichlidae & $\begin{array}{l}\text { Tristramella simonis } \\
\text { intermedia* (Steinitz and } \\
\text { Ben-Tuvia 1960) }\end{array}$ & $\begin{array}{l}\text { Tristramella simonis } \\
\text { intermedia* (Steinitz and Ben- } \\
\text { Tuvia 1960) }\end{array}$ & \\
\hline \multicolumn{2}{|c|}{$S=$ number of species } & $S=17$ species & $S=13$ species & $S=260$ species \\
\hline
\end{tabular}

\section{Discussion}

The advanced and sophisticated cognitive abilities described above are supported by a series of additional observations drawn from various multidisciplinary studies of the GBY Acheulian record. These include aspects of planning and communication as derived from stone tool production sequences (Sharon et al.2011), spatial cognition of the landscape and intra-site spatial organisation (Goren-Inbar and Sharon 2006; Rabinovich et al. 2006;

Rabinovich et al. 2008), procedural cognition, technical and procedural knowhow and specialisation (Madsen and Goren-Inbar 2004; Alperson-Afil et al. 2009; Goren-Inbar 2011; Goren-Inbar et al. 2011; Rabinovich and Biton 2011), as well as social cognition (Goren-Inbar et al. 2002b; GorenInbar2011). These cognitive abilities are expressed in the multiphase process of 
realisation of the plan for achieving a particular goal. This is seen especially in the chainne opératoire of basalt bifaces (handaxes and cleavers), documenting cognitive abilities in the structure of the long-term processes involved in biface manufacture.

In addition to the above cultural observations based on lithic assemblages and their reduction sequences, there is also evidence derived from the faunal record at the site. This is characterised by both richness and diversity of species, contributing substantially to the reconstruction of hominin knowledge of the environment in exploitation of both terrestrial wildlife (Rabinovich et al. 2012; Rabinovich and Biton 2011), such as modern-like processing of Dama sp. (Rabinovich et al. 2008), and aquatic resources such as turtles (Hartman 2004) and fish (Alperson-Afil et al. 2009; Zohar and Biton 2011).

\begin{tabular}{|c|c|c|}
\hline Species & GBY remnant & Edible organs \\
\hline Ceratophyllum demersum L. & nutlet & leaf \\
\hline Euryale ferox Salisb. & seed coat & seed \\
\hline Nuphar lutea (L.) Sm. & seed coat & leaf, petiole, rhizome \\
\hline Lemna minor $\mathrm{L}$. & - & whole plant \\
\hline Potamogeton pectinatus L. & nutlet & leaf and stem \\
\hline Trapa natans L. & nut shells & seed, root \\
\hline Utricularia australis R. Br. & - & leaf, root \\
\hline
\end{tabular}

Palaeobotanical evidence contributes to our understanding of the multiple facets of the environmental knowledge of Acheulian hominins and their ability to structure modes of exploitation of diverse resources. At GBY, this exploitation of multiple resources includes that of seven fruit-bearing species with edible nuts belonging to both extant Mediterranean vegetation and locally extinct species 
(Goren-Inbar et al. 2002a; Melamed 2003; Melamed et al. 2011). Two of the locally extinct species (in the Mediterranean biome) are edible aquatic nuts that flourished in paleo-Lake Hula and were found in quantities at the site: $E$. ferox and T. natans (Goren-Inbar et al. 2000; Goren-Inbar et al. 2002a; Rabinovich et al. 2012) (Table 3). The pitted stones and anvils mentioned above support the view that these remains were components of the paleo-diet (GorenInbar et al. 2002a). These were found in close spatial proximity with burned flint microartefacts, the latter indicating the location of Acheulian hearths (GorenInbar et al. 2002a; Goren-Inbar et al. 2004). Evidence of fire is seen throughout the sequence of Acheulian occupation at GBY (around 50,000 years at the site; Sharon et al. 2011) and attests to use and control of this component of culture. Continual fire making (Goren-Inbar et al. 2004) and the transmission of particular modes of technological tool production indicate evolved communication within the group, interpreted as language (Alperson-Afil and Goren-Inbar2010; Sharon et al. 2011). Clearly, long-term memory was already a component of the evolutionary realm of GBY hominins. The exploitation of $E$. ferox at GBY, supplemented by data from ethnographic parallels, indicates that Acheulian hominins implemented complex strategies to extract maximum nutritive value from plant species, despite the opportunity of consuming them fresh. It also suggests delayed gratification implied by the time gap between appearance and collecting of the nuts. We do not claim that Acheulian hominin cognitive abilities were similar to those of modern humans, but do suggest that some aspects of complex cognition possibly overlapped in these hominins.

Ethnographic analogies, when considered with archaeological evidence of nuts, pitted anvils and charred organic material, among other features, point to the possibility of a complex sequence of exploitation of an aquatic nut that included gathering by diving, underwater processing, drying, roasting and possibly popping. This process adds to a plethora of evidence of Acheulian hominin activities and diverse associated cognitive abilities, all of which emerge from the analyses of early Middle Pleistocene Acheulian finds from the Levantine Corridor. 


\section{Acknowledgements}

We thank Professor Vidyanath Jha, who shared with us his expert knowledge of E. ferox. Mr Ranjay Kumar Jha organised the field visit to Madhubani District, Bihar, India, and along with Mr Bhogi Mukhiya helped us to document procedures. We are grateful to G. Hivroni for the graphic design (Figures 1 and 4), Gabi Laron for photography of Figure 10a, and to Dr Y. Langsham for the SEM photography. K.A. and S.P. thank the Sharma Centre for Heritage Education for logistic aid. Botanical remains are stored at the Mina and Everard Goodman Faculty of Life Sciences, Bar-Ilan University, Ramat-Gan 5290000, Israel. At the faculty, the macrobotanical remains are stored at the National Natural History Collection (seeds). We are grateful to the two reviewers: Professor Lyn Wadley and an anonymous reviewer who helped us improve the article.

The study of the fish remains was supported by the Israel Science Foundation (Grant No. 300/06) to the Center of Excellence Project Title: 'The Effect of Climate Change on the Environment and Hominins of the Upper Jordan Valley between ca. 800Ka and 700Ka ago as a Basis for Prediction of Future Scenarios' and the Irene Levi Sala CARE Archeological Foundation. 


\section{Bibliography}

Ahmad, S.H. and Singh, A.K. 2003 'Scope of integration of Makhana with fish culture' in R.K. Mishra, V. Jha and P.V. Dehadrai (eds) Makhana, New Delhi: Directorate of Information and Publications of Agriculture, Indian Council of Agricultural Research. 85-97.

Alperson-Afil, N., Sharon, G., Zohar, I., Biton, R., Melamed, Y., Kislev, M.E., Ashkenazi, S., Rabinovich, R., Werker, E., Hartman, G. and Goren-Inbar, N. 2009 'Spatial organization of hominin activities at Gesher Benot Ya'aqov, Israel', Science 326, 1677-80. http://dx.doi.org/10.1126/science.1180695

Alperson-Afil, N. and Goren-Inbar, N. 2010 The Acheulian Site of Gesher Benot Ya'aqov: Ancient Flames and Controlled Use of Fire, Dordrecht:

Springer. http://dx.doi.org/10.1007/978-90-481-3765-7

Ashkenazi, S., Klass, K., Mienis, H.K., Spiro, B. and Abel, R. 2009 'Fossil embryos and adult Viviparidae from the early-middle Pleistocene of Gesher Benot Ya'aqov, Israel: ecology, longevity and fecundity', Lathaia 43, 11627. http://dx.doi.org/10.1111/j.1502-3931.2009.00178.x

Ashkenazi, S., Motro, U., Goren-Inbar, N., Bitton, R., and Rabinovich, R. 2005 'New morphometric parameters for assessment of body size and population structure in freshwater fossil crab assemblage from the Pleistocene site of Gesher Benot Ya'aqov (GBY), Israel', Journal of Archaeological Science 32, 67589. http://dx.doi.org/10.1016/j.jas.2004.12.003

Beaune, S.A. de 2000 Pour Une Archéologie du Geste, Paris: CNRS Editions.

Belitzky, S. 2002 'The structure and morphotectonics of the Gesher Benot Ya'aqov area, northern Dead Sea rift, Israel', Quaternary Research 58, 372-80. http://dx.doi.org/10.1006/qres.2002.2347

Colonese, A.C., Mannino, M. A., Mayer, D.E.B.-Y., Fa, D.A., Finlayson, J.C., Lubell, D. and Stiner, M.C. 2011 'Marine mollusc exploitation in Mediterranean prehistory: an overview', Quaternary International 239, 86103. http://dx.doi.org/10.1016/j.quaint.2010.09.001

Cortés-Sánchez, M., Morales-Muñiz, A., Simón-Vallejo, M.D., Lozano-Francisco, M.., Vera-Peláez, J.L., Finlayson, C., Rodríguez-Vidal, J., Delgado-Huertas, A., 
Jiménez-Espejo, F.J., Martínez-Ruiz, F., Martínez-Aguirre, M.A., PascualGranged, M.A.J., Bergadá-Zapata, M.M., Gibaja-Bao, J.F., Riquelme-Cantal, J.A., López-Sáez, J.A., Rodrigo-Gámiz, M., Sakai, S., Sugisaki, S., Finlayson, G., Fa, D.A. and Bicho, N.F. 2011 'Earliest known use of marine resources by Neanderthals', PLoSONE 6(9): e24026.

http://dx.doi.org/10.1371/journal.pone.0024026

Cunnane, S. and Stewart, K.M. (eds) 2010 Human Brain Evolution, New York: John Wiley and Son.

Danin, A. 2004 Distribution Atlas of Plants in the Flora Palaestina Area, Jerusalem: Israel Academy of Sciences and Humanities.

Feibel, S.C. 2001 'Archaeological sediments in lake margin environments' in J.K. Stein and W.R. Farrand (eds) Sediments in Archaeological Contexts, Salt Lake City: University of Utah Press. 127-48.

Feibel, C.S. 2004 'Quaternary lake margins of the Levant Rift Valley' in N. Goren-Inbar and J.D. Speth (eds) Human Paleoecology in the Levantine Corridor, Oxford: Oxbow Books. 21-36.

Gaudzinski-Windheuser, S., Kindler, L., Rabinovich, R. and Goren-Inbar, N. 2010 'Testing heterogeneity in faunal assemblages from archaeological sites. Tumbling and trampling experiments at the early middle Pleistocene site of Gesher Benot Ya'aqov (Israel)', Journal of Archaeological Science 37, 3170-90.

http://dx.doi.org/10.1016/j.jas.2010.07.018

Ghosh, S.K and Santra, S.C. 2003 'Past and present distributional records of Makhana and future prospects of its cultivation in West Bengal' in R.K. Mishra, V. Jha and P.V. Dehadrai (eds) Makhana, New Delhi: Directorate of Information and Publications of Agriculture, Indian Council of Agricultural Research. 3-7.

Gibbard, P.L., Aalto, M.M., Coope, G.R., Currant, A.P., McGlade, J.M., Peglar, S.M., Preece, R.C., Turner, C., Whiteman, C.A. and Wrayton, R.C. 1996 'Early Middle Pleistocene fossiliferous sediments in the Kesgrave Formation at Broomfield, Essex, England' in C. Turner (ed) The Early Middle Pleistocene in Europe, Rotterdam: Balkema. 83-119.

Goren-Inbar, N. 2011 'Culture and cognition in the Acheulian industry - a case study from Gesher Benot Ya'aqov', Philosophical Transactions of the Royal 
Society of London Series B 366, 1038-49.

http://dx.doi.org/10.1098/rstb.2010.0365

Goren, M. and Ortal, R. 1999 'Biogeography, diversity and conservation of the inland water fish communities in Israel', Biological Conservation 89(1), 19. http://dx.doi.org/10.1016/S0006-3207(98)00127-X

Goren-Inbar, N. and Sharon, G. 2006 'Invisible handaxes and visible Acheulian biface technology at Gesher Benot Ya'aqov, Israel' in N. Goren-Inbar and G. Sharon (eds) Axe Age: Acheulian Tool-making from Quarry to Discard, London: Equinox. 111-35.

Goren-Inbar, N., Lister, A., Werker, E. and Chech, M. 1994 'A butchered elephant skull and associated artifacts from the Acheulian site of Gesher Benot Ya'aqov, Israel', Paléorient 20(1), 99-112.

Goren-Inbar, N., Feibel, C.S., Verosub, K.L., Melamed, Y., Kislev, M.E., Tchernov, E. and Saragusti, I. 2000 'Pleistocene milestones on the Out-of-Africa corridor at Gesher Benot Ya'aqov, Israel', Science 289, 944-74.

http://dx.doi.org/10.1126/science.289.5481.944

Goren-Inbar, N., Sharon, G., Melamed, Y. and Kislev, M. 2002a 'Nuts, nut cracking, and pitted stones at Gesher Benot Ya'aqov, Israel', Proceedings of the National Academy of Sciences USA 99(4), 2455-60.

http://dx.doi.org/10.1073/pnas.032570499

Goren-Inbar, N., Werker, E. and Feibel, C.S. 2002b The Acheulian Site of Gesher Benot Ya'aqov: The Wood Assemblage, Oxford: Oxbow Books.

Goren-Inbar, N., Alperson, N., Kislev, M.E., Simchoni, O., Melamed, Y., BenNun, A. and Werker, E. 2004 'Evidence of hominin control of fire at Gesher Benot Ya'aqov, Israel', Science 304, 725-27.

http://dx.doi.org/10.1126/science.1095443

Goren-Inbar, N., Grosman, L. and Sharon, G. 2011 'The technology and significance of the Acheulian giant cores of Gesher Benot Ya'aqov, Israel', Journal of Archaeological Science 38, 1901-17.

http://dx.doi.org/10.1016/j.jas.2011.03.037 
Goren-Inbar, N., Sharon, G., Herzlinger, G. and Alperson-Afil, N. (in prep) 'A newly identified type of Acheulian basalt anvil from Gesher Benot Ya'aqov, Israel'.

Goswami, M.M. 2003 'Ecology of Euryale ferox Salisb. in flood plain wetlands of Assam' in R.K. Mishra, V. Jha and P.V. Dehadrai (eds) Makhana, New Delhi: Directorate of Information and Publications of Agriculture, Indian Council of Agricultural Research. 29-35.

Hardy, B.L. and Moncel, M.-H. 2011 'Neanderthal use of fish, mammals, birds, starchy plants and wood 125-250,000 years ago', PLosONE 6(8). e23768 http://dx.doi.org/10.1371/journal.pone.0023768

Hartman, G. 2004 'Long-term continuity of a freshwater turtle (Mauremys caspica rivulata) population in the Northern Jordan Valley and its paleoenvironmental implications' in N. Goren-Inbar and J.D. Speth (eds)Human Paleoecology in the Levantine Corridor, Oxford: Oxbow Books. 61-74.

Jain, A., Singh, H.B. and Kanjilal, P.B. 2010 'Economics of Foxnut (Euryale ferox Salisb.) cultivation: a case study from Manipur in North eastern India', Indian Journal of Natural Products and Resources 1(1), 63-67.

Jain, A, Sundriyal, M., Roshnibala, S., Kotoky, R., Kanjilal, P.B., Singh, H.B. and Sundriyal, R.C. 2011 'Dietary use and conservation concern of edible wetland plants at Indo-Burma hotspot: a case study from northeast India', Journal of Ethnobiology and Ethnomedicine 7, 29. http://dx.doi.org/10.1186/1746-4269-7$\underline{29}$

Jha, V. and Barat, G.K. 2003 'Nutritional and medicinal properties of Euryale ferox Salisb.' in R.K. Mishra, V. Jha and P.V. Dehadrai (eds) Makhana, New Delhi: Directorate of Information and Publications of Agriculture, Indian Council of Agricultural Research. 230-38.

Jha, V., Kargupta, A.N., Dutta, R.N., Jha, U.N., Mishra, R.K. and Saraswati, K.C. 1991 'Utilization and conservation of Euryale ferox Salisbury in Mithila (North Bihar), India', Aquatic Botany 39, 295-314.http://dx.doi.org/10.1016/0304$\underline{3770(91) 90005-P}$

Jha, V., Verma, A.M. and Jha, A.K. 2003 'Indigenous contrivances utilized in Makhana cultivation in north and north-eastern India' in R.K. Mishra, V. Jha 
and P.V. Dehadrai (eds) Makhana, New Delhi: Directorate of Information and Publications of Agriculture, Indian Council of Agricultural Research. 241-48.

Joordens, J.C.A., Wesselingh, F.B., de Vos, J., Vonhof, H.B. and Kroon, D. 2009 'Relevance of aquatic environments for hominins: a case study from Trinil (Java, Indonesia)', Human Evolution 57, 656-

\section{1.http://dx.doi.org/10.1016/j.jhevol.2009.06.003}

Khan, M.S. and Halim, M. 2003 'Makhana, Euryale ferox Salisb. in Bangladesh' in R.K. Mishra, V. Jha and P.V. Dehadrai (eds) Makhana, New Delhi: Directorate of Information and Publications of Agriculture, Indian Council of Agricultural Research. 23-28.

Madsen, B. and Goren-Inbar, N. 2004 'Acheulian giant core technology and beyond: an archaeological and experimental case study', Eurasian Prehistory 2, $3-52$.

Mandal, R.N., Saha G.S. and Sarangi, N. 2010 'Harvest and processing of Makhana (Euryale ferox Salisb.) - a unique assemblage of traditional knowledge', Indian Journal of Traditional Knowledge 9(4), 684-88.

Melamed, Y. 2003 Reconstruction of the Hula Valley vegetation and the hominid vegetarian diet by the Lower Palaeolithic botanical remains from Gesher Benot Ya'aqov, Unpublished PhD thesis, Bar-Ilan University (in Hebrew).

Melamed, Y., Kislev, M.E., Weiss, U. and Simchoni, O. 2011 'Extinction of water plants in the Hula Valley: evidence for climate change', Journal of Human Evolution 60, 320-27.http://dx.doi.org/10.1016/j.jhevol.2010.07.025

Mienis, H.K. and Ashkenazi, S. 2011 'Lentic basommatophora molluscs and hygrophilous land snails as indicators of habitat and climate in the early-middle Pleistocene (0.78 Ma) site of Gesher Benot Ya'aqov (GBY)', Journal of Human Evolution 60, 328-40. http://dx.doi.org/10.1016/j.jhevol.2010.03.009

Miki, S. 1960 'Nymphaeaceae remains in Japan, with new fossil genus Eoeuryale', Journal of the Institute of Polytechechnics 11(D), 63-78.

Mishra, R.K., Jha, V. and Dehadrai, P.V. (eds) 2003 Makhana, New Delhi: Directorate of Information and Publications of Agriculture, Indian Council of Agricultural Research. 
Montana, G., Choudhary, S.K., Dey, S. and Winemiller, K.O. 2011 'Compositional trends of fisheries in the River Ganges, India', Fisheries Management and Ecology 18, 282-96. http://dx.doi.org/10.1111/j.1365-2400.2010.00782.x

Rabinovich, R. and Biton, R. 2011 'The early-middle Pleistocene faunal assemblages of Gesher Benot Ya'aqov - taphonomy and paleoenvironment', Journal of Human Evolution 60, 35774.http://dx.doi.org/10.1016/j.jhevol.2010.12.002

Rabinovich, R., S. Gaudzinski-Windheuser, and N. Goren-Inbar 2006 Site Formation Processes - The Role of Hominin and Natural Agents in the Formation of Striations and Cut Marks on Bones at the Acheulian site of Gesher Benot Ya'aqov, Israel, Final Report, Jerusalem: German-Israeli Foundation for Scientific Research and Development.

Rabinovich, R., Gaudzinski, S. and Goren-Inbar, N. 2008 'Systematic butchering of Fallow deer (Dama) at the early middle Pleistocene Acheulian site of Gesher Benot Ya'aqov, (Israel)', Journal of Human Evolution 54, 134-49.

Rabinovich, R., Gaudzinski-Windheuser, S., Kindler, L. and Goren-Inbar, N. 2012 The Acheulian Site of Gesher Benot Ya'aqov: Mammalian Taphonomy - The Assemblages of Layers V-5 and V-6, Dordrecht:

Springer. http://dx.doi.org/10.1007/978-94-007-2159-3

Sharon, G. and Goren-Inbar, N. 1999 'Soft percussor use at the Gesher Benot Ya'aqov Acheulian site?', Journal of the Israel Prehistoric Society 28, 55-79.

Sharon, G., Alperson-Afil, N. and Goren-Inbar, N. 2011 'Cultural conservatism against variability in the continual Acheulian sequence of Gesher Benot Ya'aqov, Israel', Journal of Human Evolution 60, 387-

97.http://dx.doi.org/10.1016/j.jhevol.2009.11.012

Simpson, J.B. 1936 'Fossil pollen in Scottish Tertiary coal', Proceedings of the Royal Society of Edinburgh 56, 90-108.

Singh, P.K. 2003 'Distribution and uses of Makhana in Manipur' in R.K. Mishra, V. Jha and P.V. Dehadrai (eds) Makhana, New Delhi: Directorate of Information and Publications of Agriculture, Indian Council of Agricultural Research. 8-13. 
Singh, A.V. and Singh, P.K. 2011 'Nutritional, ethnotherapeutics and socioeconomic relevance of Euryale Ferox Salisb. in Manipur, India', Life Sciences Leaflets 22, 1104-15.

Soboleweska, U.S. 1970 'Euryale ferox Salisb. in the Pleistocene of Poland', Acta Palaeobotanica 11, 13-20.

Spiro, B., Ashkenazi, S., Mienis, H.K., Melamed, Y., Feibel, C., Estacion, A.D. and Starinsky, A. 2009 'Climate variability in the Upper Jordan Valley around 0.78 $\mathrm{Ma}$, inferences from time-series stable isotopes of Viviparidae, supported by mollusc and plant palaeoecology', Palaeogeography, Palaeoclimatology, Palaeoecology 282, 32-44. http://dx.doi.org/10.1016/j.palaeo.2009.08.005

Stewart, K.M. 1994 'Early hominid utilisation of fish resources and implications for seasonality and behaviour', Journal of Human Evolution 27, 22945. http://dx.doi.org/10.1006/jhev.1994.1044

Stewart, L.M. 2010 'The case for exploitation of wetlands environments and floods by pre-Sapiens hominins' in S.C. Cunnane and K.M. Stewart (eds) Human Brain Evolution. The Influence of Freshwater and Marine Food Resources, Hoboken, New Jersey: John Wiley and Sons. 137-

\section{1.http://dx.doi.org/10.1002/9780470609880.ch8}

Verhaegen, M. and Munro, S. 2011 'Pachyosteosclerosis suggests archaic Homo frequently collected sessile littoral foods', HOMO Journal of Comparative Human Biology 62, 237-47.http://dx.doi.org/10.1016/j.jchb.2011.06.002

Wrangham, R., Cheney, D., Seyfarth, R. and Sarmiento, E. 2009 'Shallow-water habitats as sources of fallback foods for hominins', American Journal of Physical Anthropology 140, 630-42.http://dx.doi.org/10.1002/ajpa.21122

Zohar, I. and Biton, R. 2011 'Land, lake, and fish: investigation of fish remains from Gesher Benot Ya'aqov (paleo-lake Hula)', Journal of Human Evolution 60, 343-56. http://dx.doi.org/10.1016/j.jhevol.2010.10.007 